\title{
Phylobioactive hotspots identified through multidimensional profiling of botanical drugs used to treat Chagas disease in Bolivia and Dioscorides' De Materia Medica
}

\author{
Andrea Salm ${ }^{1 *}$, Sandhya R. Krishnan ${ }^{1 *}$, Marta Collu ${ }^{1,2}$, Ombeline Danton ${ }^{3}$, Matthias Hamburger ${ }^{3}$, \\ Marco Leonti ${ }^{2}$, Giovanna Almanza ${ }^{4}$, Jürg Gertsch ${ }^{1}$
}

${ }^{1}$ Institute of Biochemistry and Molecular Medicine, University of Bern, Switzerland, ${ }^{2}$ Department of Science and Biomedicine, University of Cagliari, Italy, ${ }^{3}$ Department of Pharmaceutical Sciences, University of Basel, Switzerland, ${ }^{4}$ Instituto de Investigaciones Quimicas, Universidad Mayor de San Andres, Bolivia

* authors contributed equally to the study 


\begin{abstract}
Globally, more than six million people are infected with Trypanosoma cruzi, the causative protozoan parasite of the vector-borne Chagas disease (CD). In Bolivia, CD is hyperendemic and a major health problem among indigenous communities. Although botanical drugs are used widely among different ethnic groups in Bolivia, studies challenging the hypothesis that effective antitrypanosomal medicinal agents were identified empirically are lacking. We conducted a cross-sectional ethnopharmacological field study in Bolivia among different ethnic groups in the Chaco, Chiquitanía and Inter-Andean valleys. We compared botanical drugs used in Bolivia in the context of $C D$ with botanical drugs from unrelated indications from the Mediterranean De Materia Medica (DMM) compiled by Dioscorides two thousand years ago. A total of 775 ethyl acetate plant extracts with and without ethnomedical indications for $C D$ treatment were profiled against $T$. cruzi epimastigote and procyclic $T$. brucei proliferation, parasite release from $T$. cruzi trypomastigote infected cells, as well as for host cell cytotoxicity in vitro. Inhibition of parasite release was monitored using a flow cytometry-based celluar assay. At $25 \mu \mathrm{g} / \mathrm{mL}$, less than $5 \%$ of all extracts exhibited selective toxicity for $T$. cruzi. We found no evidence that ethnomedicine-inspired bioprospecting significantly increased the probability of finding selective antichagasic botanical drugs. The ethnomedical data further indicate a discrepancy between local and scientific concepts about CD among the studied ethnic groups. Intriguingly, the phylobioactive anthraquinone hotspot identified in this study matched the antichagasic activity of Senna chloroclada, the taxon with the strongest consensus for treating CD among the Izoceño-Guaraní. Selected antitrypanosomal plant extracts from DMM were subjected to HPLC-based activity profiling and targeted isolation of active compounds yielding sesquiterpene lactones, naphtoquinones and anthraquinones. Because the anthraquinone emodin selectively and potently inhibited $T$. cruzi in host cell infection, we performed a preliminary structure-activity relationship analysis for the 9,10-anthracenedione scaffold, exploring the impact of differential hydroxylation. This study shows that the multidimensional phylobioactivity-guided identification of antichagasic natural products enables comparative bioprospecting and is suitable to challenge ethnopharmacological hypotheses.
\end{abstract}




\section{Author summary}

Chagas disease (CD) is a parasitic disease caused by the protozoan Trypanosoma cruzi. In Bolivia, CD is a major health problem among indigenous communities, which frequently use traditional medicine to treat the chronic symptoms of the disease related to cardiomyopathy. However, the ethnomedical context of the use of such remedies is largely unclear and it remains unknown whether the botanical drugs have any effect on parasitemia. In a field study among different ethnic groups in the Chaco, Chiquitanía and Inter-Andean valleys the authors collected ethnobotanical and ethnopharmacological information. Later, they profiled and compared the CD botanical drug extract library from Bolivia with a botanical drug extract library from the Mediterranean De Materia Medica with no association to $C D$. Using phylogenetic and biological information, they identified bioactive hotspots among different taxa and isolated antichagasic natural products. This led to a first structureactivity relationship study of the natural product class called anthraquinones. While there was no overall statistical difference between the libraries, it is noteworthy that the botanical drug derived from Senna chloroclada with the highest consensus among the Guaraní communities, also belonged to the anthraquinone cluster, potentially providing a molecular explanation for its use.

\section{Introduction}

Chagas disease (CD) or American trypanosomiasis is the disease caused by infection of the haemoflagellate protozoan Trypanosoma cruzi (1). The parasitic T. cruzi is mainly transmitted to humans by hematophagous Reduviid bugs of the subfamily Triatominae (Triatoma spp.) (1-3). Other means of transmission involve blood transfusion, organ transplant, congenitally, and oral contamination $(1,2)$. CD is classified as one of the most neglected tropical diseases, especially among low-income populations (4). The WHO estimates that about 6 to 7 million people are infected worldwide, primarily in Latin America, where the disease is endemic (5). Bolivia has the highest CD incidence in the world $(6,7)$, and $T$. cruzi infection has a high prevalence in different rural areas, primarily affecting the indigenous communities in the Inter-Andean valleys and the Chaco (7-9).

$C D$ presents two clinical phases. The acute stage of the disease (i.e. infection) remains often unperceived and only very rarely morbidity and mortality occur (10). In some cases, the sites of bug bites get inflamed and form nodules called chagoma or "Romaña sign" when the protozoan enters via the conjunctiva. After an incubation period of less than two weeks, newly infected individuals may develop fever, chills, myalgia, rash or meningeal irritation. However, the initial chagoma can remain the only indication of $T$. cruzi infection for years. At the chronic stage, parasitism and inflammation of the heart and/or enlarged colon can result in severe pathophysiological endpoints, including megacolon, megaoesophagus and cardiomyopathy (11). Cardiomyopathy manifests as arrhythmias, congestive heart failure or sudden cardiac arrest. During the chronic phase, T. cruzi infection can present an indeterminate form, where, depending on the $T$. cruzi strain and possibly host immunity, approximately $70 \%$ of the infected individuals remain completely asymptomatic $(2,3,12)$. Currently, there are two approved drugs that are used to treat acute $C D$, namely the nitroheterocyclic compounds nifurtimox (Lampit ${ }^{\circledR}$ ) and benznidazole (Rochagan ${ }^{\circledR}$ ). However, there is a controversy about their efficacy in chronic $C D(13,14)$ and both drugs show adverse effects upon prolonged administration $(15,16)$. Moreover, these antichagasic drugs are hardly accessible for the indigenous communities in Bolivia. Consequently, people living in rural areas of Bolivia rely on traditional medicines for their primary health care $(17,18)$. Botanical drugs contribute significantly to Bolivian folk medicine and they are harvested wild, cultivated and traded at local markets (19). Despite reports making general claims about the efficacy of traditional botanical drugs (20), few studies address their mode of action based on comparative hypothesis-driven ethnopharmacological 
research. It is unknown whether $C D$, which has a millennial history in the area (21), enforced a selection pressure to prompt ethnomedical strategies among the affected indigenous groups in Bolivia that directly reduce parasitemia or primarily treat the symptoms of CD.

Plants are known to produce a high diversity of secondary metabolites showing numerous pharmacological effects, including antiparasitic and antimicrobial $(22,23)$. Medicinal plants have been shown to act via different mechanisms of action also against various causative agents of neglected tropical diseases like Mycobacterium ulcerans or T. cruzi (24-26). Plant secondary metabolites have led to the development of antiprotozoal chemotherapeutics, which include antimalarials such as the alkaloid quinine from Cinchona spp. (Rubiaceae) and the sesquiterpene lactone (SL) artemisinin from Artemisia annua L. (Asteraceae) (27). Ethnopharmacology inspires bioprospecting as it investigates treatment consensus of natural drugs among ethnic groups as anecdotal indications for presumed pharmacological efficacy $(28,29)$. Considering Bolivia's rich biocultural diversity and the endemic nature of $C D$, ethnopharmacological and bioprospecting studies focusing on antichagasic remedies are surprisingly scarce (30-33). In parallel, few studies were dedicated to the ethnomedicine and management of $C D$ in Bolivia $(34,35)$. Although different plant extracts and natural products have been reported to exert moderate $\left(\mathrm{IC}_{50}\right.$ values $\left.\leq 100 \mu \mathrm{g} / \mathrm{mL}\right)$ to significant $(15 \leq \mu \mathrm{g} / \mathrm{mL})$ selective toxicity towards $T$. cruzi epimastigotes (36-39), reports on activity against trypomastigote cellular infection and amastigote replication in vitro are relatively rare. Overall, systematic and comparative antitrypanosomal screenings with comprehensive extract libraries derived from botanical drugs are lacking, thus hindering a direct comparison of efficacy.

The aim of the present study was to conduct a cross-sectional ethnopharmacological study among the indigenous groups Quechua, Izoceño-Guaraní, Ayoreo and Chiquitano to investigate their prevalent ethnomedical strategies to treat $C D$ in Bolivia. This included the documentation of the knowledge about botanical drugs used in treating CD-related symptoms. Fieldwork involved structured and semi-structured interviews, plant collections (drug samples and herbarium vouchers), and identification of the plant taxa used. An ethyl acetate (EtOAc) extract library of the botanical drugs used to treat $C D$ was generated for in vitro testing against trypanosomes. To validate the ethno-directed bioprospecting approach, we also profiled in vitro antitrypanosomal effects of EtOAc extracts obtained from Mediterranean botanical drugs described in De Materia Medica (DMM), written by Dioscorides in the first century AD (40). We hypothesized that the CD botanical drug library would result in a comparatively higher number of extracts showing selective antichagasic activity in vitro. Using phylobioactivity-guided profiling in combination with HPLC-based activity profiling of active extracts we tested whether bioactive phylogenetic clusters can serve as a basis for the more efficient characterization of antichagasic plant metabolites. The DMM extract library yielded phylogenetic patterns of activity and different active hotspots could be identified representing chemotaxonomic associations. This multidimensional profiling resulted in a first preliminary structure-activity relationship (SAR) study on the antitrypanosomal effects of anthraquinones on parasite release upon host cell infection by trypomastigotes in vitro.

\section{Methods}

\section{Ethnopharmacological fieldwork}

The study was carried out among four indigenous groups (Quechua, Izoceño-Guaraní, Chiquitano and Ayoreo), settled in geographically distinct rural areas in Bolivia (Fig. 1). The surveyed Quechua communities were located in the Inter-Andean valleys between 3000 and 2200 m.a.s.l. in the municipality of Mizque (Cochabamba Department). The Guaraní in Bolivia live in the Chaco region, which is a semi-arid plain grassland, interspersed with swamps and thorny forests, that extends across southeast lowland Bolivia. In Bolivia, there are three subgroups of Guaraní (Ava, Simba and 
Izoceño), marked by linguistic and historical differences. We visited communities of the IzoceñoGuaraní in the municipality of Charagua (Santa Cruz Department). The Chiquitano informants lived in the lowland Chiquitanía region situated in the Santa Cruz Department. This region is an ecologically transitional zone between the arid plains of the Chaco and the tropical rain forests. Today, Chiquitanos are native Spanish speakers. The survey was carried out in the Chiquitano communities in the municipalities of Concepción, San José de Chiquitos and Roboré. The Ayoreo groups used to live in the Chaco but have been sedentarized and acculturated by missionaries in the mid twentieth century. We surveyed Ayoreo communities situated in the Chiquitanía region (municipalities of Concepción, Pailón and San José de Chiquitos) and Ayoreo informants who lived in the city of Santa Cruz. All visited indigenous communities were small settlements located in rural areas characterized by a low population density. The main economic activity was subsistence farming. Traditional dwellings were predominantly constructed of adobe walls, earthen floors and thatched roofs, and constitute an ideal habitat for the CD vector T. infestans (41). T. cruzi transmission was hyperendemic showing the highest infection rates in the Chaco region and Inter-Andean valleys (42-46). Biomedical health care was mainly provided by primary health centers located in the bigger villages Charagua, La Brecha and lyovi (Chaco), San José de Chiquitos, Roboré and Concepción (Chiquitanía), Mizque and Laguna Grande (Inter-Andean valleys). However, most of them were insufficiently equipped, and CD treatment was marginally successful (41). Additionally, a survey was conducted in the herbal markets of the cities of La Paz and Santa Cruz de la Sierra.

Fieldwork was carried out between June 2014 and May 2015 in all study sites during all vegetation periods. The survey was directed towards the management of CD related symptoms and associated knowledge. Before starting with the survey, the project was presented to the local authorities and to the communities (Fig. 1) during initial meetings for approval. Local research participants were randomly selected according to their availability, willingness and individual interest while each participant represented a distinct household. Interviews took place at the participants' home and were conducted in Spanish, or in their native language (Guaraní, Ayoreo, Quechua) with the assistance of a local translator. In the cities, we interviewed the medicinal plant vendors at the herbal markets from where we directly purchased the botanical drugs. Ethnomedical and ethnopharmacological information was obtained through structured and semi-structured interviews, free listing of remedies, observing practices in situ and by collecting plant material during walk-inthe-woods together with the participants. During interviews, representative photographs of chagoma were shown and symptoms of chronic CD (cardiomyopathy, megacolon, megaoesophagus) described to the participants for eliciting focused responses. Questions targeted ethnomedical concepts related to $C D$ and plant taxa used for treatment of acute and chronic symptoms. Vernacular plant names, parts used, dosage, mode of preparation and administration, provenance and availability were documented. Botanical voucher specimens were collected with the help of local informants, prepared and deposited at the National Herbarium in Bolivia (LPB) under the collection ID ASMPx. Botanical identification was carried out by specialists at LPB, and botanical names standardized in accordance with the theplantlist.org (47) and plant families following Angiosperm Phylogeny Group 4 (APG IV, 2016) (48). Data were analyzed with basic descriptive statistics such as the quantification of individual use reports cited by the informants according to current standards and recommendations (49).

\section{Ethics statement}

Field research was approved by the Ministerio de Ambiente y Desarrollo Sostenible through a collaboration with the Instituto de Investigaciones Quimicas The institutional review board (IRB) of the Universidad Mayor de San Andres (UMSA FCPN) as part of the National Bioethics Committee approved the study. Oral consent was obtained from each research participant for treating personal 
data and the recording of ethnomedical information. Community consent was documented on video or tape. Written consent at the time of the study was not feasible as the majority of participants were illiterate.

\section{Collection of botanical drugs mentioned in De Materia Medica}

Botanical drugs mentioned in DMM and associated voucher specimens were collected in several locations in Europe and the Mediterranean area, cultivated in domestic gardens or purchased from commercial suppliers between 2014 and 2016. Plant taxa were identified using the Flora Europea (50). Only those 660 botanical drugs, whose botanical description in DMM permitted a taxonomic identification (40) were collected. Prior to solvent extraction samples were dried at $40-60{ }^{\circ} \mathrm{C}$. Herbarium voucher specimens were identified at the Department of Biomedical Science (University of Cagliari) and voucher specimens deposited at the Herbarium of the Botanical Garden of Geneva (Switzerland) and at the Herbarium of the National and Kapodistrian University of Athens (ATHU).

\section{Preparation of extracts}

Medicinal plant parts used in the context of CD were collected in situ and from the same collections herbarium voucher specimens were prepared. The clean plant materials (roots washed) were airdried in the shade and stored dry in cotton bags at $-20{ }^{\circ} \mathrm{C}$ prior to extraction. The extracts were generated as follows: Air-dried and powdered $(0.5 \mathrm{~mm})$ plant material was used for the preparation of semipolar extracts. The samples were exhaustively extracted by maceration with EtOAc $(99.8 \%$, Sigma Aldrich) at room temperature for $48 \mathrm{~h}$. EtOAc (polarity index $\mathrm{P}=4.4$ ) was used based on its optimal extraction for secondary metabolites that are apolar to semipolar, excluding the highly polar constituents like sugars and polymers. Upon filtration (Whatman, $2.5 \mu \mathrm{m}$ ), samples were concentrated under reduced pressure on a rotary evaporator. The dried extracts were used to prepare stock solutions of $5 \mathrm{mg} / \mathrm{mL}$ in dry DMSO ( $\geq 99 \%$, Sigma Aldrich) for subsequent use in in vitro assays. Crude extracts and DMSO stock solutions were stored at $-20^{\circ} \mathrm{C}$.

\section{Biological assays}

\section{In vitro activity against $T$. cruzi epimastigotes}

Antitrypanosomal activity was first evaluated against epimastigotes of $T$. cruzi ( $\mathrm{Y}$ strain obtained from ATCC) by the XTT assay $(51,52)$. Since all known antichagasic agents show toxicity also against the epimastigote form, we used this screening as a preselective assay. Parasites were maintained in liver infusion tryptose medium (LIT) supplemented with $10 \%$ FBS (fetal bovine serum) at $27{ }^{\circ} \mathrm{C}$, prepared according to the recommendations by ATCC. Epimastigotes in exponential growth phase were counted, adjusted to a concentration of $1.5 \times 10^{6}$ parasites $/ \mathrm{mL}$, and exposed to 6 concentrations of each plant extract (in DMSO) ranging from $100 \mu \mathrm{g} / \mathrm{mL}$ to $0.8 \mu \mathrm{g} / \mathrm{mL}$ for $72 \mathrm{~h}$ at $27^{\circ} \mathrm{C}$. For the $D M M$ library we chose a concentration of $25 \mu \mathrm{g} / \mathrm{mL}$ based on recommendations for the pure compounds (53). The assays were carried out in 96 -well plates ( $200 \mu \mathrm{L} /$ well). After $72 \mathrm{~h}$ of incubation, the plates were inspected under an inverted microscope to assure growth of the controls and sterile conditions. $50 \mu \mathrm{L}$ of a XTT (Sigma Aldrich, MO, USA)/PMS (phenazine methosulfate, Sigma Aldrich, MO, USA) solution ( $0.5 \mathrm{mg} \mathrm{XTT/0.025} \mathrm{mg} \mathrm{PMS/mL} \mathrm{in} \mathrm{PBS)} \mathrm{were} \mathrm{added} \mathrm{to} \mathrm{the} \mathrm{plates.} \mathrm{The} \mathrm{parasites} \mathrm{were} \mathrm{further}$ incubated at $27^{\circ} \mathrm{C}$ for $3 \mathrm{~h}$. Then, methanol (50 $\mathrm{LL} /$ well) was added, and the plates were incubated for $10 \mathrm{~min}$ to fix the parasites. Absorbance was determined spectrophotometrically at $490 \mathrm{~nm}$ on a Tecan plate reader. DMSO was used as negative control, and benznidazole and nifurtimox (both Sigma Aldrich, Switzerland) were used as positive controls. Results were expressed as $\mathrm{IC}_{50}$ and calculated by GraphPad Prism $5^{\circledR}$. Each assay was carried out at least in three independent experiments each in triplicate.

In vitro activity against procyclic T. brucei brucei 
The T. b. brucei procyclic form (427 strain) was cultured at $27^{\circ} \mathrm{C}$ in SDM79 medium, supplemented with 5\% FBS and hemin, as reported (54). Parasites in exponential growth phase were counted, adjusted to a concentration of $1.0 \times 10^{6}$ parasites $/ \mathrm{mL}$ and exposed to plant extracts for $72 \mathrm{~h}$ at $27^{\circ} \mathrm{C}$. The assays were carried out in 96 -well plates $(100 \mu \mathrm{L} /$ well). After $72 \mathrm{~h}$ of incubation, the plates were inspected under an inverted microscope to enusre growth of the controls and sterile conditions. 10 $\mu \mathrm{L}$ MTT ( $5 \mathrm{mg} / \mathrm{mL}$ in PBS) were added to the plates. The cells were further incubated for 4 hours at $27{ }^{\circ} \mathrm{C}$. After incubation the purple formazan precipitates were solubilized in DMSO ( $200 \mu \mathrm{L} /$ well). Absorbance was determined spectrophotometrically at $550 \mathrm{~nm}$. DMSO was used a negative, and nifurtimox as positive control. Results were expressed as $\mathrm{IC}_{50}$ calculated by GraphPad Prism $5^{\circledR}$ from the sigmoidal concentration-response curve. Each assay was carried out in triplicate for the initial profiling.

\section{Cytotoxicity measurements in HeLa, CHO and Raw264.7 cells}

Cytotoxicity/antiproliferative assays were performed by the MTT method as reported previously (55).

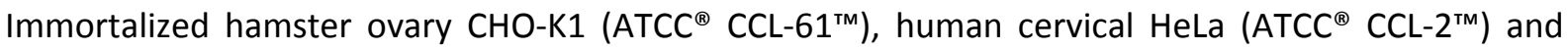
mouse macrophage Raw264.7 (ATCC ${ }^{\oplus}$ TIB-71 ${ }^{\mathrm{TM}}$ ) cells were cultured in RPMI-1640 medium supplemented with $10 \% \mathrm{FBS}$ at $37{ }^{\circ} \mathrm{C}$ in $5 \% \mathrm{CO}_{2}$ atmosphere. Cells were counted and adjusted to a final concentration of $2 \times 10^{4}$ cells $/ \mathrm{mL}$. $100 \mu \mathrm{L}$ were seeded in 96-well plates and incubated for $24 \mathrm{~h}$ at $37{ }^{\circ} \mathrm{C}$ with $5 \% \mathrm{CO}_{2}$. Then, $100 \mu \mathrm{L}$ medium containing plant extracts at various concentrations (from $100 \mu \mathrm{g} / \mathrm{mL}$ to $0.8 \mu \mathrm{g} / \mathrm{mL}$ ) were added. Plates were again incubated for $72 \mathrm{~h}$ at $37{ }^{\circ} \mathrm{C}$ with $5 \% \mathrm{CO}_{2}$. After incubation, the plates were inspected under an inverted microscope to assure growth of the controls and sterile conditions. Medium was removed and $90 \mu \mathrm{L}$ fresh culture medium and $10 \mu \mathrm{L}$ MTT $\left(5 \mathrm{mg} / \mathrm{mL}\right.$ in PBS) were added to the each well. Plates were incubated for 4 hours at $37{ }^{\circ} \mathrm{C}$ with $5 \% \mathrm{CO}_{2}$. Subsequently, the purple formazan precipitate was solubilized in DMSO (200 $\mu \mathrm{L} /$ well) and absorbance determined spectrophotometrically at $550 \mathrm{~nm}$. Cells cultured in absence of compounds were used as control of viability (negative control). Results were expressed as $\mathrm{IC}_{50}$ or as \% cell viability of negative control calculated with GraphPad Prism $5^{\circledR}$. Each assay was carried out in triplicate in three independent experiments.

\section{Parasite release from trypomastigote-infected cells using flow cytometry}

The EtOAc extracts from the CD library and the active antitrypanosomal extracts from the $D M M$ library were evaluated in an in vitro model of $T$. cruzi parasite relase assay in $\mathrm{CHO}$ cells using analytical fluorescence activated cell scanning (FACS). In this assay, it was possible to simultaneously assess inhibition of growth and release of the parasite from infected host cells, which are relevant disease parameters. The host cells were cultured in RPMI-1640 medium supplemented with $10 \%$ FBS at $37{ }^{\circ} \mathrm{C}$ in $5 \% \mathrm{CO}_{2}$ atmosphere. Metacyclogenesis of epimastigotes (strain $\mathrm{Y}$ ) was induced by Grace insect medium (Sigma Aldrich, MO, USA) supplemented with $10 \% \mathrm{FBS}$ and hemin $(25 \mu \mathrm{g} / \mathrm{mL}$, Sigma Aldrich, MO, USA). Trypomastigotes were generated by infecting $\mathrm{CHO}$ cells with metacyclic trypomastigotes harvested after 9 days of cultivation in Grace medium $(56,57)$. Trypomastigotes of $T$. cruzi were obtained from the extracellular medium of infected $\mathrm{CHO}$ cells at day 5 post infection. $\mathrm{CHO}$ cells were counted and adjusted to a final concentration of $8 \times 10^{4}$ cells $/ \mathrm{mL}$. $500 \mu \mathrm{L}$ were seeded in 24well plates and incubated for $24 \mathrm{~h}$ at $37{ }^{\circ} \mathrm{C}$ with $5 \% \mathrm{CO}_{2}$. Subsequently, cells were infected with trypomastigotes in fresh medium without FBS at a multiplicity of infection (MOI) of 1:10 and incubated at $37^{\circ} \mathrm{C}$ in $5 \% \mathrm{CO}_{2}$ for $24 \mathrm{~h}$. During this time, trypomastigotes were allowed to invade host cells. After infection, the medium containing non-internalized parasites was removed and cells were washed twice with PBS. $500 \mu \mathrm{L}$ of fresh RPMI medium without FBS containing plant extracts or controls (vehicle or benznidazole) were added. Plates were then incubated for 5 days at $37{ }^{\circ} \mathrm{C}$ with $5 \% \mathrm{CO}_{2}$. After incubation, the plates were inspected under an inverted microscope to assure cell 
viability and sterile conditions. To determine the antitrypanosomal effects, trypomastigotes (and residual amastigotes from burst cells) were collected from the extracellular medium and transferred into Eppendorf tubes. Infected CHO cells were washed twice with PBS and the washing PBS was collected in the tubes containing the released parasites. Parasites were pelleted and resuspended in PBS and incubated with $50 \mathrm{nM}$ SYTO9 (S34854) dye for 30 min at $37{ }^{\circ} \mathrm{C}$ with $5 \% \mathrm{CO}_{2}$. Following this, the parasites were fixed using 4\% PFA in PBS for $2 \mathrm{~h}$ at RT. A relative quantitation of the released parasite population was done via fluorescence-associated cell sorting (FACS) on a FACScan (BD Biosciences) equipped with a solid-state laser (Cytek, Cambridge, UK) at $485 \mathrm{~nm}$ excitation and 535 $\mathrm{nm}$ emission (FL1). Each plate also contained non-infected untreated controls (blanks: $0 \%$ released parasites), infected untreated controls (negative control: 100\% released parasite) and reference controls (positive control: benznidazole at $20 \mu \mathrm{M}$ ). Results were expressed as \% released parasites compared to the negative control. Each assay was carried out in three independent experiments each in triplicates.

\section{Biosafety}

Experimental work with live T. cruzi were carried out following standard operating procedures in compliance with biosafety level $3^{*}$ regulations (BSL3*) approved by the safety authorities of the University and Canton of Bern, Switzerland: The Standard Operational Procedures of the experiments were reported to the Swiss Authority Federal Office of Public Health (BAG).

\section{Comparison of EtOAc plant extract libraries}

Hit rates were defined and calculated for both the Bolivian $C D$ and the $D M M$ extract libraries. For host cell cytotoxicity, the hit criterion was $>50 \%$ HeLa growth inhibition at $25 \mu \mathrm{g} / \mathrm{mL}(72 \mathrm{~h}$ incubation). The hit criterion for antichagasic activity was $>50 \% T$. cruzi epimastigote growth inhibition at $25 \mu \mathrm{g} / \mathrm{mL}$ ( $72 \mathrm{~h}$ incubation). The criterion for potentially selective antichagasic activity was $>50 \% T$. cruzi epimastigote growth inhibition at $25 \mu \mathrm{g} / \mathrm{mL}$ and $<50 \%$ inhibition of HeLa or CHO cellular proliferation at $25 \mu \mathrm{g} / \mathrm{mL}$. The null hypothesis of the statistical test was that no relationship exists on the categorical variables (probability of hits) in the equally heterogeneous (genera and families) extract libraries, which were independent and with a reasonable sample size (>100 and $<700$ ). Results related to general cytotoxicity and selective antichagasic effects were compared with the $X^{2}$ test and $P$-values were calculated. A $P$-value $<0.05$ was considered as statistically significant. We investigated the phylogenetic distribution of plant species with the ggtree package (36) in the $R$ environment Version 3.5.0 (http://www.R- project.org/).

\section{Microfractionation, bioactivity-guided isolation and structure elucidation}

General Experimental Procedures. Optical rotations were measured in chloroform or methanol on a Jasco P-2000 digital polarimeter (Tokyo, Japan) with a $10 \mathrm{~cm}$ microcell. Nuclear magnetic resonance (NMR) spectra were recorded on a Bruker AVANCE III $500 \mathrm{MHz}$ spectrometer (Billerica, CA, USA) operating at $500.13 \mathrm{MHz}$ for $1 \mathrm{H}$ and $125.77 \mathrm{MHz}$ for $13 \mathrm{C}$. Measurements were performed with a 1 $\mathrm{mm}$ TXI probe at $18^{\circ} \mathrm{C}$. Data were processed with Bruker TopSpin 3.5 software. HR-ESIMS data were recorded in positive ion mode on a Thermo Scientific Orbitrap LQT XL mass spectrometer (Waltham, MA, USA). Centrifugal partition chromatography (CPC) was performed on an Armen Instrument (AlphaCrom, Rheinfelden, Switzerland) with coil volume $100 \mathrm{~mL}$ connected to a Varian pump model 210 (Agilent technologies, Santa Clara, CA, USA), a Varian 218 UV detector and a Varian fraction collector (model 704). Preparative reversed-phase high performance liquid chromatography (RPHPLC) was carried out on a Puriflash 4100 system (Interchim, Montluçon, France) with a Waters (Milford, MA, USA) SunFire Prep C18 OBD column $(5 \mu \mathrm{m}, 30 \times 150 \mathrm{~mm}$ i.d., guard column $10 \times 20 \mathrm{~mm}$ i.d.). Semipreparative RP-HPLC was performed on an Agilent 1100 Series instrument with a DAD detector (Santa Clara, CA, USA) and a Waters (Milford, MA, USA) SunFire C18 column (5 $\mu \mathrm{m}, 150 \times 10$ 
mm i.d., guard column $10 \times 10 \mathrm{~mm}$ i.d.). An HPLC system consisting of degasser, binary mixing pump, autosampler, column oven, and a diode array detector (all Shimadzu, Kyoto, Japan) connected via a T-splitter to an Alltech 3300 ELSD detector (Büchi, Flawil, Switzerland) and a Shimadzu 8030 triple quadrupole MS system with ESI and APCI interfaces was used for HPLC analysis. Data acquisition and processing were performed with LabSolution software (Kyoto, Japan). Separations were achieved with a SunFire C18 column $(3.5 \mu \mathrm{m}, 150 \times 3.0 \mathrm{~mm}$ i.d., guard column $10 \mathrm{~mm} \times 3.0 \mathrm{~mm}$ i.d.) (Waters, Milford, MA, USA). Microfractionation was carried out on the same instrument, but with a FC 204 fraction collector (Gilson, Middleton WI, USA) connected instead of the MS. Microfractions were collected into 96-deepwell plates. HPLC grade acetonitrile (Macron Fine Chemicals, Avantor Performance Materials, Phillipsburg, NJ, USA) and water from a Milli-Q water purification system (Merck, Darmstadt, Germany), and formic acid from Merck were used for HPLC separations. NMR spectra were recorded in DMSO-d6, methanol-d4 or chloroform-d (Armar Chemicals, Döttingen, Switzerland).

Microfractionation and isolation of natural products from selected extracts was carried out for subsequent testing on epimastigote viability/proliferation ( $72 \mathrm{~h}$ incubation assay) and in the parasite release assay. For microfractionation, extracts were dissolved in DMSO $(10 \mathrm{mg} / \mathrm{mL})$ and separated by gradient HPLC [0.1\% aq. formic acid (A), 0.1\% formic acid in acetonitrile (MeCN) (B); 0-30 min (5-100 $\% \mathrm{~B}$ ); flow rate $0.4 \mathrm{~mL} / \mathrm{min}$; injection volume $4 \times 30 \mu \mathrm{L}$; room temperature]. Optimized gradients were used for Laurus nobilis leaf extract [0-5 min (5-30\% B), 5-30 min (30-100\% B)] and Sium sisarum root extract [0-5 $\mathrm{min}(5-40 \% \mathrm{~B}), 5-30 \mathrm{~min}$ (40-1000 \% B)]. One-minute fractions were collected in 96-deep-well plates. Plates were dried in a Genevac EZ-2 evaporator (Ipswich, UK), and microfractions in wells redissolved in DMSO prior to bioassays. Compounds in the active time windows were isolated as follows: $200.6 \mathrm{mg}$ of EtOAc extract of Rumex crispus rhizome were submitted to preparative RP-HPLC [water (A), MeCN (B); 0- 15 min (40-60\% B), 15-30 min (60\% B), $30-50 \mathrm{~min}(60-100 \% \mathrm{~B})$; flow rate $20 \mathrm{~mL} / \mathrm{min}$; injection volume $2 \times 2 \mathrm{~mL}$; room temperature] afforded compounds nepodin ( $28.2 \mathrm{mg}$, tR $19.3 \mathrm{~min}$ ), torachrysone (2.7 mg, tR $23.9 \mathrm{~min}$ ), emodin (1.67 mg, tR $24.7 \mathrm{~min}$ ), and chrysophanol (8.0 mg, tR $38.9 \mathrm{~min}) .24 .0 \mathrm{mg}$ of EtOAc extract of $\mathrm{S}$. sisarum roots were purified by semipreparative RP-HPLC [water (A), MeCN (B); 0-5 min (5-40 \% B), 5-20 min (40-70\% B), 20-30 min (70\% B); flow rate $4 \mathrm{~mL} / \mathrm{min}$; injection volume $3 \times 400 \mu \mathrm{L}$; room temperature] to yield falcarindiol $(7.1 \mathrm{mg}$, tR $21.8 \mathrm{~min}) .30 .0 \mathrm{mg}$ of EtOAc extract of Rheum rhaponticum roots were separated by semipreparative RP-HPLC [water (A), MeCN (B); 0-20 min (5$60 \% \mathrm{~B}$ ), 20-30 min (60\% B); flow rate $4 \mathrm{~mL} / \mathrm{min}$; injection volume $3 \times 500 \mu \mathrm{L}$; room temperature] to afford (6R, 7S)-costunolide (1.1 mg, tR $26.3 \mathrm{~min}) .2 .0 \mathrm{~g}$ of $L$. nobilis leaf extract were separated by CPC [Hexane/EtOAc/MeOH/water, 7/3/5/5, v/v/v/v]; 0-60 min (descending mode), 60-72 min (ascending mode); flow rate $5 \mathrm{~mL} / \mathrm{min}$; rotation $2000 \mathrm{rpm}$; injection volume $10 \mathrm{~mL}$ ]. Separation was monitored by the HPLC gradient mentioned above and detection at $210 \mathrm{~nm}$. Active compounds were in fractions F2 (18-20 $\mathrm{min}), \mathrm{F} 6(46-49 \mathrm{~min}), \mathrm{F9}(67-72 \mathrm{~min})$. These fractions were further purified by semipreparative RP-HPLC [water (A), MeCN (B); flow rate $4 \mathrm{~mL} / \mathrm{min}$; injection volume $3 \times 500 \mu \mathrm{L}$; room temperature]. F2 (32.0 mg) [0-45 min (25\% B)] yielded compounds (+)-reynosin (3.8 mg, tR $26.6 \mathrm{~min})$, zaluzanin C (1.6 mg, tR $29.2 \mathrm{~min})$, and santamarine $(2.7 \mathrm{mg}, \mathrm{tR} 39.7 \mathrm{~min})$. F6 (13.0 mg) [0-30 min (42\% B)] afforded (3S)-3-acetylzaluzanin C (4.2 mg, tR $23.8 \mathrm{~min})$, and F9 (44.0 mg) [0-30 min (40-65 \% B)] yielded costunolide (14.1 mg, tR $21.9 \mathrm{~min})$, dehydrocostus lactone (5.3 mg, tR 23.7 $\mathrm{min})$, and eremanthin $(2.4 \mathrm{mg}, \mathrm{tR} 24.7 \mathrm{~min})$.

Nepodin: amorphous solid; HR-ESI-MS m/z $217.0850[\mathrm{M}+\mathrm{H}]^{+}\left(\right.$calcd for $\left.\mathrm{C}_{13} \mathrm{H}_{13} \mathrm{O}_{3}{ }^{+}, 217.0859\right)$.

Torachrysone: amorphous solid; HR-ESI-MS m/z $247.0963[\mathrm{M}+\mathrm{H}]^{+}$(calcd for $\left.\mathrm{C}_{14} \mathrm{H}_{15} \mathrm{O}_{4}{ }^{+}, 247.0965\right)$.

Emodin: amorphous solid; HR-ESI-MS m/z $271.0598[\mathrm{M}+\mathrm{H}]^{+}$(calcd for $\left.\mathrm{C}_{15} \mathrm{H}_{11} \mathrm{O}_{5}{ }^{+}, 271.0601\right)$. 
Chrysophanol: amorphous solid; HR-ESI-MS m/z $255.0649[\mathrm{M}+\mathrm{H}]^{+}$(calcd for $\mathrm{C}_{15} \mathrm{H}_{11} \mathrm{O}_{4}{ }^{+}, 255.0652$ ).

(3R, 8S)-Falcarindiol: oil; $[\alpha]_{\mathrm{D}}{ }^{25}+285\left(0.1, \mathrm{CHCl}_{3}\right) ; \mathrm{APCl}-\mathrm{MS} \mathrm{m} / \mathrm{z} 262[\mathrm{M}+\mathrm{H}]^{+}$.

(6R, 7S)-Costunolide: amorphous solid; $[\alpha]_{D}^{25}+108\left(0.1, \mathrm{CHCl}_{3}\right) ; \mathrm{HR}-\mathrm{ESI}-\mathrm{MS} \mathrm{m} / \mathrm{z} 233.1527[\mathrm{M}+\mathrm{H}]^{+}$ (calcd for $\mathrm{C}_{15} \mathrm{H}_{21} \mathrm{O}_{2}{ }^{+}, 233.1536$ ).

(+)-Reynosin: amorphous solid; $[\alpha]_{D}^{25}+59\left(0.2, \mathrm{CH}_{3} \mathrm{OH}\right)$; ESI-MS m/z $249[\mathrm{M}+\mathrm{H}]^{+}$.

Zaluzanin C: amorphous solid; $[\alpha]_{D}{ }^{25}+37\left(0.1, \mathrm{CHCl}_{3}\right)$; ESI-MS m/z $247[\mathrm{M}+\mathrm{H}]^{+}$.

Santamarine: amorphous solid; $[\alpha]_{D}{ }^{25}+83\left(0.1, \mathrm{CH}_{3} \mathrm{OH}\right)$; ESI-MS m/z $249[\mathrm{M}+\mathrm{H}]^{+}$.

(3S)-3-acetylzaluzanin C: amorphous solid; $[\alpha]_{\mathrm{D}}{ }^{25}+15\left(0.1, \mathrm{CHCl}_{3}\right)$; ESI-MS m/z $289[\mathrm{M}+\mathrm{H}]^{+}$.

Dehydrocostus lactone: amorphous solid; $[\alpha]_{D}^{25}-6\left(0.1, \mathrm{CHCl}_{3}\right)$; ESI-MS m/z $231[\mathrm{M}+\mathrm{H}]^{+}$.

Eremanthin: amorphous solid; $[\alpha]_{D}^{25}-276\left(0.1, \mathrm{CHCl}_{3}\right)$; ESI-MS m/z $231[\mathrm{M}+\mathrm{H}]^{+}$.

For the SAR analysis with 9,10-anthracenedione, the following commercial compounds were purchased ( $\geq 95 \%$ purity). Anthraquinone (1), alizarin (4), alizarin RedS (5), quinizarin (6), anthrarufin (7), anthraflavic acid (9), emodin (2), purpurin (3), rhein (15), diacerein (16), chrysophanol (10), disperse Red11 (17) and dantron (8) were all obtained from Sigma Aldrich, Switzerland. Aloe emodin (11), physcion (12), 2-hydroxy-3-methylanthraquinone (13) and 2-hydroxy-1-methylanthraquinone (14) were obtained from Toronto Research Chemical, ON, Canada. Aurantio obtusin (18) was obtained from AdooQ Biosciences LLC, CA, USA. 


\section{Results}

\section{Ethnopharmacological survey in Bolivia}

Ethnomedical data were obtained from a total of 361 informants in three different geographic areas representing four ethnic groups (Fig. 1). In total, 152 research participants (5 Ayoreo, 68 Chiquitano, 54 Izoceño-Guaraní, 19 Quechua and 6 sellers from the city markets) reported ethnomedical knowledge related to the treatment of CD (Table 1). In our study, the gender of the informants was uniformly distributed, and we were not able to detect gender-specific knowledge related to the treatment of $C D$. When asked about $C D$ and its symptoms, informants of all ethnic groups showed a lack of ethnomedical knowledge related to the pathophysiology of $C D$. Unlike other disease categories, such as dermatological affections or diseases of the digestive system, chronic CD was recognized unambiguously only after diagnosis by blood tests in the health centers or hospitals. Symptoms related to cardiomyopathies (general fatigue, shortness of breath, dizziness, chest pain, heart palpitations, high blood pressure and swelling of feet and legs) were generally associated to CD among the Chiquitano and Izoceño-Guaraní. Botanical drugs used for $C D$ were most frequently associated with these symptoms. The survey resulted in more than 350 use reports for 79 plant taxa used in the context of CD (Table 2). Of these, 69 were identified to the species level, 9 plants were identified to the genus level, and one taxon was identified only to the family level. The recorded remedies comprised plant taxa distributed across 37 botanical families and 74 genera (Table 2). From the plants identified to the species level, $80 \%$ were native to Bolivia. Only 41 medicinal plant species (52\%) were collected wild, while the others were obtained through cultivation or from local markets. Decoctions and infusions in cold and hot water, respectively, were the most common preparation forms for oral administration. Informants reported that the chronic symptoms were relieved after taking these plant remedies. The most cited plant species to be effective in the treatment of symptoms related to CD were Senna chloroclada (flowers, root) (Fig. 3) and Tabebuia aurea (bark), followed by the introduced and globally known medicinal plant species Alpinia zerumbet (rhizome) and Cymbopogon citratus (herb) (Table 2). Noteworthy, Chiquitano informants also reported a blend of several botanical drugs against CD, such as a combination of the barks of Jacaranda cuspidifolia, $T$. aurea and Trichilia sp. Particularly interesting in the context of this study was that few informants stated that certain botanical drugs could cure chronic CD, namely S. chloroclada (flowers, root), Cochlospermum tetraporum (bark, leaves) and Bulnesia bonariensis (bark). However, there was no consensus among independent informants. Even during prolonged stays, the use of these remedies was observed rarely by the authors. Only the use of Galphimia brasiliensis (root) (Fig. 3) could be repeatedly observed among the Chiquitano. To treat triatomine bites, topical application as poultices were mentioned (Table 2). Informants agreed that acute symptoms and inflammatory swellings (chagoma) at the bite sites occurred very rarely. Nocturnal triatomine bites were considered common and harmless. In highly affected communities (Izoceño-Guaraní and Ayoreo) informants stated that the bites were irritating but not painful and therefore remained mostly untreated. Only the taxa Aloe vera, Croton sp. and Verbesina sp were reported to be used for triatomine bites. Bauhinia sp., S. chloroclada and Parthenium hysterophorus were mentioned as a treatment of fever during first infections (Table 2). Besides plant based remedies, eleven Chiquitano informants reported the use of animal products, such as Coragyps atratus (black vulture; blood), Tapirus sp. (tapir; nails) and Equus africanus asinus (donkey; milk) to treat the chronic symptoms of CD. Few Izoceño-Guaraní informants also reported the use of grease of armadillos (Dasypoda spp.) against triatomine bites, and others applied alcohol topically. The plant taxa used for CD obtained in markets were common medicinal plants known to be used for a variety of diseases and ailments (Table 2).

The Quechua and Ayoreo reported relatively fewer remedies to manage $C D$ as compared to the Izoceño-Guaraní and Chiquitano (Table 1), despite the high prevalence of CD in their communities (> 
40\%; Fig. 2). The vast majority of the Ayoreo interviewed in this study did not report any botanical drugs used in the context of CD (Fig. 2). The visited Ayoreo communities were evangelic or catholic Christians that stopped practicing shamanism decades ago. Generally, they had no or little knowledge about traditional medicinal agents. Although Quechua informants have been educated on the association between triatomine bugs and CD by institutional anti-CD campaigns (41), they had a very limited understanding about the transmission mechanisms and symptoms of the illness. There was poor consensus among Quechua informants and we obtained only one or two use-reports for each plant taxon, with the exception of Minthostachys ovata aerial parts ( 3 use-reports, Table 2 ). Most of the reported plants used by the Quechua were native to the region (86\% of the total number of identified taxa at species level) and were gathered from the wild (74\%). Among the Quechua, traditional healers (curanderos) generally carried out the preparation of botanical drugs. Although there were specialized healers among the Izoceño-Guaraní (paye) and Chiquitano communities, the knowledge and use of botanical drugs was not restricted to them. Guaraní and Chiquitano community members used botanical drugs to alleviate CD-associated symptoms because they lacked alternatives, and ethnomedical remedies were easily accessible. Especially in the Guaraní communities there was a general lack of primary health care, and travelling to Santa Cruz posed significant difficulties for patients.

\section{Analysis of plant libraries}

\section{Biological profiling of CD botanical drug library, collected in Bolivia}

Crude EtOAc extracts obtained from 115 botanical drugs, representing 79 plant species and collected on the basis of their use in the management of CD (Table 2), were dissolved in DMSO and tested in vitro for their antitrypanosomal activity against $T$. cruzi epimastigotes and procyclic $T$. b. brucei, as well as for general cytotoxic effects in HeLa and Raw264.7 cells. Antiproliferative $\mathrm{IC}_{50}$ values $<25$ $\mu \mathrm{g} / \mathrm{mL}$ were considered biologically significant. To define selective hits, a cutoff of $50 \%$ inhibition (HeLa antiproliferative effect) at $25 \mu \mathrm{g} / \mathrm{mL}$ was used. $\mathrm{IC}_{50}$ values were determined only for selective hits. Supplementary Table $1 \mathrm{~S}$ summarizes the results obtained in the in vitro bioassays with the plant extracts. Phylogenetic distribution of reported anti-CD plant taxa and screening results are shown in Fig. 4. In general, the T. b. brucei strain was very sensitive towards the tested extracts and, rather surprisingly, 90 extracts (78\%) exhibited antitrypanosomal activity against procyclic $T$. b. brucei (Fig. 4). In contrast, only $20(17 \%)$ extracts inhibited $T$. cruzi epimastigotes with $\mathrm{IC}_{50}$ values $\leq 25 \mu \mathrm{g} / \mathrm{mL}$. Seven extracts $(6 \%)$ showed pronounced $\left(\mathrm{IC}_{50}<10 \mu \mathrm{g} / \mathrm{mL}\right)$ and 13 extracts $(10 \%)$ good $\left(\mathrm{IC}_{50} \leq\right.$ $25 \mu \mathrm{g} / \mathrm{mL}$ ) antitrypanosomal activity (Fig. 4). The most potent extracts were those of Cynara sp. aerial parts $(2 \mu \mathrm{g} / \mathrm{mL})$, Acanthostyles buniifolius aerial parts $(2 \mu \mathrm{g} / \mathrm{mL})$ and Gochnatia boliviana leaves (4 $\mu \mathrm{g} / \mathrm{mL}$ ) (Fig. 4). The extracts from roots and flowers of $S$. chloroclada, the most frequently cited anti$C D$ botanical drugs among the Guaraní, were not active against epimastigotes $\left(I_{50} \mathrm{~S}>50 \mu \mathrm{g} / \mathrm{mL}\right.$ ), while an extract of the aerial parts of this plant was moderately active. The $S$. chloroclada flower extract showed significant inhibitory effects on parasite release in the infection assay $(15 \mu \mathrm{g} / \mathrm{mL}$ were equally effective as $20 \mu \mathrm{M}$ of benznidazole) without being cytotoxic to host cells (Suppl. Table S1). The ESI-MS scan and a positive TLC Borntrager reaction indicated that this plant contained anthraquinones and possibly anthrones and its glycosides. Since many extracts exhibited significant general cytotoxicity (Fig. 4), the observed toxicity against epimastigotes could also be due to nonspecific effects. Moreover, cytotoxic extracts $(27.8 \%)$ could not be analyzed in the trypomastigote infection assay. Particularly cytotoxic extracts were from Ambrosia arborescens leaves, G. boliviana leaves, G. boliviana branches, Bocconia integrifolia leaves, B. integrifolia roots, Cynara sp. aerial parts, and $P$. hysterophorus aerial parts. The only highly active and selective antitrypanosomal extracts were from Pterodon sp. seeds, Sonchus oleraceus leaves, A. buniifolius aerial parts, Aloysia 
polystachya aerial parts and Gloxinia gymnostoma aerial parts (Fig. 4). The extracts of these taxa showed also significant inhibitory effects in the T. cruzi infection assay (Suppl. Table S1).

As initial IC $\mathrm{C}_{50}$ values were obtained in anti-proliferation assays with $T$. cruzi epimastigotes, we next screened the extracts lacking general cytotoxicity in the cellular infection assay. In order to validate the antitrypanosomal activity on the mammalian stage forms that are relevant for the disease, extracts were tested for their ability to inhibit $T$. cruzi parasite release assay in CHO cells. Amastigotes develop intracellularly, differentiate into trypomastigotes and leave the host cell. Here we quantified the amount of trypomastigotes released (and residual amastigotes in case cells burst prematurely). To that aim, we developed a versatile FACS-based assay by staining released parasites in supernatant using a DNA stain. Benznidazole was used to validate the assay system (Fig. 5). Although the assay showed significant variability $( \pm 30 \%)$, due to the nature of independent $T$. cruzi infections and overall variability in replication efficiencies, a reliable $\mathrm{IC}_{50}$ value for benznidazole could be obtained $(2 \pm 0.4 \mu \mathrm{M})$, which was in agreement with previously published data (58). Consequently, we employed this assay for our profiling of the CD botanical drug library, whereby initial testing of the extracts was performed at a single concentration $(15 \mu \mathrm{g} / \mathrm{mL})$. As shown in Table 1S, extracts which were active against $T$. cruzi epimastigotes were generally also active in the infection assay, with the exception of $S$. chloroclada. The pre-screening with epimastigotes was thus considered suitable for the discovery of antichagasic compounds able to inhibit different stages of the infection/replication cycle.

\section{Comparative profiling of the DMM library from the Mediterranean}

To validate the ethno-directed approach for bioprospecting antichagasic activity, we compared the results obtained for botanical drugs used in a CD context with those of 660 botanical drugs described in Dioscorides' $D M M$. Importantly, the botanical drugs mentioned in $D M M$ show no traditional association with CD. EtOAc extracts were tested at $25 \mu \mathrm{g} / \mathrm{mL}$ in vitro against $T$. cruzi epimastigotes, and on HeLa cells for cytotoxicity (Fig. 6, Suppl. Table 2S). The extracts were considered active (i.e. hits) when the percentage of inhibition was $\geq 50 \%$ at $25 \mu \mathrm{g} / \mathrm{mL}$. A total of 59 (8.9\%) extracts exhibited antitrypanosomal activity while 102 (15.5\%) extracts were cytotoxic towards HeLa cells (Fig. 6; Suppl. Table 2S). Among the antitrypanosomal hits, only 27 extracts (4.1\%) were selectively toxic for T. cruzi epimastigotes. Extracts with apparent selectivity were those obtained from Levisticum officinale fruits, Opopanax chironium roots, Glebionis coronaria flowers, Tanacetum parthenium flowers, Convolvulus scammonia roots, Iris foetidissima seeds, Laurus nobilis fruits, Rheum rhaponticum roots, Rumex crispus roots and Ruta chalepensis roots. Extracts with selective toxicity for $T$. cruzi epimastigotes were considered potential hits and their antichagasic activity was subsequently determined at $15 \mathrm{\mu g} / \mathrm{mL}$ in the trypomastigote infection assay in CHO cells. All extracts with the exception of those obtained from $A$. vera resin, L. nobilis leaves and L. albus roots were also active in the infection assay (>50\% inhibition of parasite release at $15 \mu \mathrm{g} / \mathrm{mL}$ ).

\section{Comparison of extract libraries derived from different ethnopharmacological contexts}

In an attempt to pharmacologically validate the ethno-directed approach, hit rates were calculated for both the CD and DMM botanical drug libraries. The Pearson $X^{2}$ test was applied for statistics. Results show that there is a significantly higher probability $(17.4 \%$ vs. $8.9 \%, P=0.0057)$ of detecting antichagasic ( $T$. cruzi epimastigotes) extracts when the plant had a reported use against CD. However, we also found a significantly higher percentage of cytotoxic ( $\mathrm{IC}_{50} \leq 25 \mu \mathrm{g} / \mathrm{mL}$ ) extracts among CD botanical drugs $(27.8 \%$ vs. $15.5 \%, P=0.0012)$. Taking the importance of selectivity into account, the hit rate of selective antichagasic extracts in vitro was not considered statistically different $(P=0.079)$ between the Bolivian CD $(7.8 \%)$ and the DMM $(4.1 \%)$ extract libraries. The two libraries shared 20 genera and included the identical species $S$. oleraceus, Spartium junceum, A. vera, 
Linum usitatissimum and $R$. chalepensis (Suppl. Tables $1 S$ and 2 S). Only S. oleraceus and S. junceum aerial parts were also identical botanical drugs.

\section{Microfractionation of selected extracts and identification of antitrypanosomal natural products}

For the isolation of potentially antichagasic metabolites related to the $D M M$ library, active extracts from different phylogenetic clusters were selected (Fig. 6). A major phylogenetic hotspot showing trypanocidal selectivity was the 'anthraquinone cluster' with $R$. crispus (curly dock) and $R$. rhaponticum (rhapontic rhubarb) rhizomes from the Polygonaceae family (Fig. 6). As anticipated, anthraquinones and naphthoquinones were major active principles in $R$. crispus (Fig. 7) and $R$. rhaponticum (not shown). The latter also yielded the SL $(6 R, 7 S)$-costunolide. L. nobilis (bay) leaves from the Lauraceae family were also studied. Noteworthy, all plant parts of L. nobilis showed significant antichagasic effects (Suppl. Table S2). The L. nobilis leaf extract, which inhibited epimastigote proliferation but was inactive in the infection assay, yielded the known SLs (+)-reynosin, zaluzanin C, santamarine, (3S)-3-acetylzaluzanin C, dehydrocostus lactone and eremanthin. Since all of these SLs showed antiproliferative effects in CHO cells (Table 3) we tested them in the infection assay at the subcytotoxic concentration of $5 \mu \mathrm{M}$ only (Table 3). Sium sisarum root (skirret) from the Apiaceae family showed overall good antichagasic selectivity. However, phytochemical annotation in this case was more complex, since the polyacetylene $(3 R, 8 S)$-falcarindiol, a major metabolite from $S$. sisarum, was isolated but inactive in all assays. As illustrated with $R$. crispus, the most potent antichagasic principle was the anthraquinone emodin which completely inhibited $T$. cruzi epimastigote proliferation during the bioactivity-guided isolation and also inhibited parasite release (Fig. 7 and Table 3). Nepodin from R. crispus inhibited epimastigote proliferation $\left(\mathrm{IC}_{50}=28.7 \pm 13.3\right.$ $\mu \mathrm{M})$ but was not equally efficacious in inhibiting the parasite release in the infection assay $(\sim 30 \%$ inhibition at $5 \mu \mathrm{M})$.

\section{Impact of 9,10-anthracenedione substitutions on antichagasic effects in vitro}

Emodin (2), which was representative for the anthraquinone cluster, moderately inhibited T. cruzi epimastigote growth and significantly inhibited parasite release in the cellular infection assay without being cytotoxic to host cells up to $100 \mu \mathrm{M}$ (selectivity index of 200 (Table 3)). We therefore performed a preliminary structure-activity relationship (SAR) study on the 9,10-anthracendione (1) scaffold (Table 4). Both the inhibition of epimastigote proliferation and parasite release were measured. Our data indicate that the position of the hydroxyl groups was important for the antichagasic activity in vitro, with the trihydroxy-substituted derivatives being the most active (Table 5). The canonical anthraquinone (1) was ineffective against epimastigotes, and only very marginally active against cellular parasite release at $0.5 \mu \mathrm{M}$. Hydroxylation at R1/R2 (4) abolished this activity. Hydroxylation at R2/R6 (9) did not significantly improve activity of $\mathbf{1}$ in the infection assay. Likewise, the additional hydroxymethyl moiety at R3 found in aloe emodin (11) did not improve the activity in the infection assay but increased general cytotoxicity. Interestingly, hydroxylation at R1/R8 showed a trend towards general increase in toxicity towards epimastigotes $(\mathbf{2}, \mathbf{8}, \mathbf{1 0}-\mathbf{1 2})$. An acidic functional group $(\mathrm{COOH})$ at R2 abolished the antichagasic activity as indicated by the lack of activity of rhein (15) and its clinically used anti-rheumatic prodrug diacerein (16) (see Table 5). The replacement of hydroxyl groups with methoxy and methyl groups generally led to a decrease in activity as shown by compounds 12 and 18. Thus, 9,10-anthracenedione with hydroxyl groups at positions R1 and R3 or R4, as exemplified by compounds $\mathbf{2}, \mathbf{3}$ and $\mathbf{6}$, proved to be most active in the infection assay, but did not inhibit proliferation of epimastigotes. We also determined the long-term cytotoxicity $(72 \mathrm{~h}$ incubation) towards host cells for the anthraquinones most effectively inhibiting $T$. cruzi parasite release in $\mathrm{CHO}$ cells $(\mathbf{2}, \mathbf{3}, \mathbf{6 , 1 4})$. Noteworthy, all anthraquinones were cytotoxic only at higher micromolar concentrations, with the exception of quinizarin, which showed an $\mathrm{IC}_{50}$ value of $38 \pm 16$ $\mu \mathrm{M}$. In this study, emodin (2) was the most potent antichagasic 9,10-anthracenedione in all stages of 
T. cruzi, followed by purpurin (3), which inhibited $50 \%(52.5 \pm 14.4)$ of cellular parasite release at 0.5 $\mu \mathrm{M}$.

\section{Discussion}

\section{Biological profiling of plant extracts and assessment of the ethno-directed approach}

In the present study we document the current knowledge about botanical drugs used to manage CD by the indigenous peoples Ayoreo, Chiquitano, Izoceño-Guaraní and Quechua in Bolivia. A major aim was to use this information for bioprospecting for anti-CD drugs. Previous studies reported better antimicrobial properties of extracts derived from botanical drugs selected based on popular uses related to microbial infections (59-61). Such studies lend credit to the ethno-directed approach in bioprospecting for specific bioactive metabolites. In order to challenge this approach, we tested a total of 775 EtOAc extracts from two independent botanical drug libraries generated from 115 taxa selected for their reported use against symptoms of CD in Bolivia and from 660 taxa described in $D M M$. Although the ethnomedical extraction generally proceeded with hot water infusions, we justify the use of EtOAc for extract preparation by the reduced extraction of polar and high molecular weight compounds, such as sugars and tannins, which would potentially interfere with the screening. Our findings indicate that the CD botanical drug library contains a significantly higher percentage of cytotoxic plant taxa. However, hit rates for selectively antichagasic plant extracts in the two libraries were not significantly different. The overall higher hit rate among the $C D$ library was possibly due to non-specific cytotoxic effects, which could be conditioned by the ecological factors prevailing in the Chaco and Inter-Andean valleys. The extreme atmospheric and ecological conditions (altitude, extreme dryness and high temperature ranges) in these regions may favor the production of metabolites with broad-spectrum toxic or general antifeedant properties.

Among the indigenous peoples participating in this study, the biomedical concept of CD was only recently introduced and did not match with any existing traditional disease concept. This seems related to the fact that infection with $T$. cruzi shows a diffuse and varied disease pattern, and is asymptomatic in the majority of cases. We found that the majority of the botanical drug preparations intended for oral use (aqueous decoctions and infusions) were used to relieve symptoms associated with the chronic phase of $C D$, such as cardiac complications, fever and fatigue, and not for combatting the (invisible) parasites. In fact, most of the botanical drugs applied for CD related symptoms were also used for other therapeutic purposes involving inflammatory conditions (Table 2). We thus conclude that tangible ethnomedical concepts about CD were absent until recently and developed only during the last decades, which is in agreement with the cultural perception of $T$. cruzi vectors (41). This clearly hampers the application and selection of botanical drugs targeting $T$. cruzi parasitemia and its symptoms, and probably explains in part why the majority ( $>80 \%)$ of the extracts derived from botanical drugs with reported use against $C D$ and its symptoms were not active. The use of plant- and animal-based traditional medicine among the Chiquitano, Izoceño-Guaraní and Quechua was widespread and in agreement with previous reports that these people widely use traditional medicine despite the presence of Western healthcare $(18,62)$. Noteworthy, the Ayoreo did not treat $C D$ at all, which is in agreement with their overall very limited use of herbal medicine. Chiquitano, Izoceño-Guaraní and Quechua research participants stated that they tried to manage CD with plant-based remedies because Western health care was limited, and chemotherapy not accessible during the chronic stage of $C D$. Another study from a different region in Bolivia reported a similar situation (34). Asteraceae was the most dominant family of plants usind for $C D$, likely due to their overall abundance and species richness. In general, Asteraceae are over-proportionally represented in medical florae (63-65), and this may be linked to the high diversity of bioactive secondary metabolites in the family (63). Quechua informants showed a low consensus regarding the 
species to be used in the treatment of $C D$ with only one species mentioned three times. A higher consensus was found among the Chiquitano and Izoceño-Guaraní participants (estimated Trotter and Logan Informants' consensus: Fic $>0.8$ ) with relatively few species being used by a large proportion of participants. Among the Izoceño-Guaraní S. chloroclada (referred to as lanza lanza, mbuijare or retama) was clearly the most important species for treating CD, with a share of $48 \%$ of total usereports. Interestingly, S. chloroclada belonged to a phylogenetic cluster that showed no or little inhibition of epimastigote proliferation in the pre-screening (Fig. 4), but exhibited significant antichagasic effects in the parasite release assay $(79.5 \%$ inhibition at $15 \mu \mathrm{g} / \mathrm{mL}$ by EtOAc extract of flower). This discrepancy was also observed with some anthraquinones (purpurin and quinizarin). Since the extract likely contains glycosides that may be hydrolyzed by $\mathrm{CHO}$ cells but not by epimastigotes, we cannot exclude metabolic changes induced by host cells. The genus Senna (syn. Cassia) is known to contain anthraquinone, dianthrone and naphthol glycosides (66). A preliminary ESI-MS scan analysis and the Borntrager reaction confirmed the presence of anthraquinones (physicon and chrysophanol) in this botanical drug (supplementary Fig. S1). To date, no in-depth phytochemical study is available on S. chloroclada, and follow-up studies are planned in our laboratory. T. aurea bark as its Spanish vernacular name "paratodo" indicates, was used for numerous diseases, in agreement with a previous study (67). The introduced species A. zerumbet and C. citratus are well known in South America for the treatment of cardiovascular diseases (67-70). An apparently specific medicinal indication for CD was also reported for several species mentioned by our research participants, such as Aloysia citridora, Baccharis genistelloides, Bixa orellana, Dysphania ambrosioides, Handroanthus impetiginosus, L. usitatissimum, Plantago major, Ruta chalepensis, S. chloroclada, S. junceum and Schinus molle $(17,34,35,71-76)$. None of the EtOAc extracts obtained from botanical drugs of these species were significantly and selectively toxic against $T$. cruzi in our infection assay with the exception of $S$. chloroclada (flowers) inhibiting parasite release $>50 \%$ in vitro at $15 \mu \mathrm{g} / \mathrm{mL}$ (Suppl. Table S1) but not showing any effect on epimastigotes.

The extract obtained from the aerial parts of $A$. buniifolius (Fig. 3) had a $\mathrm{SI}>20$ and was the other noteworthy hit obtained with the CD informed library. It fully inhibited epimastigote proliferation at $25 \mu \mathrm{g} / \mathrm{mL}$ and parasite release at $15 \mu \mathrm{g} / \mathrm{mL}$. Its antichagasic and antileishmanial activity was previously reported for plant material collected in Argentina, and the flavonoid santin was thought to be the active compound (77). However, santin was only moderately active against $T$. cruzi epimastigotes and trypomastigotes $\left(\mathrm{IC}_{50}\right.$ values $\left.>30 \mu \mathrm{M}\right)$. Clearly, the presence of additional antichagasic metabolites should not be excluded, and an in-depth phytochemical investigation of $A$. buniifolius is warranted. The extract of seeds of a Pterodon sp. showed significant and apparently specific antitrypanosomal effects. Whether the very common diterpene alcohol geranylgeraniol previously identified as the major antichagasic component in Pterodon pubescens seeds (78) is responsible for this specific antitrypanosomal activity remains to be clarified.

The screening of the DMM extract library resulted in 23 extracts with selective parasite toxicity in the T. cruzi release assay. Of these extracts, eight were from Apiaceae and seven from Asteraceae showing taxonomic parallels with the CD-informed library. In both libraries, Asteraceae was the largest family. Asteraceae are known to frequently contain SLs with antiprotozoal properties $(79,80)$ (vide infra). It is possible that the use of SL containing botanical drugs could therefore represent an ethnopharmacological strategy to reduce parasitemia in CD. The 660 extracts representing the DMM library were obtained from 389 different plant species. The largest part are from the Mediterranean basin, but central European species and exotic herbal drugs imported from Africa, Arabia, Central Asia, Himalaya and the Indo-Malayan region are also included. The families with the highest share of botanical drugs and species are Apiaceae with 69 botanical drugs from 37 spp., Asteraceae with 51 botanical drugs from 33 spp., Rosaceae with 37 botanical drugs from 18 spp., Lamiaceae with 33 botanical drugs from $26 \mathrm{spp}$. and Fabaceae with 29 botanical drugs from $22 \mathrm{spp}$. This pattern reflects 
the overall taxonomic composition of $D M M$ for which a total of 536 plant taxa representing 924 botanical drugs were identified and recommended for 5314 medical applications (40). The medical categories with the most therapeutic uses are dermatology (1216), gastroenterology (805), gynecology (615), urology (437), respiratory system (374) and neurology (269). The most frequently mentioned parasite treatments are related to lice, scabies and tapeworms but also applications for malaria causing infections with Plasmodium were described (tertian and quartan fever) such as all parts of Anchusa sp., seed and leaves of Bituminaria bituminosa, root of Dipsacus fullonum, seeds of Heliotropium europaeum, root of Plantago sp., herb of Potentilla reptans and the herb of Verbena officinalis (40). With respect to the overall Mediterranean flora the Apiaceae and Rosaceae appear to be overrepresented in this library, while the frequency of Asteraceae and Lamiaceae appears to be rather consistent with the overall species diversity and abundance. Apiaceae fruits were frequently used as antidotes, and their resins for neurological and musculoskeletal problems. Considering the size of plant families, the Fabaceae seem underrepresented, while Poaceae, Caryophyllaceae and Orchidaceae are clearly underrepresented in the DMM library (Suppl. Table 2S; $(40,50)$ ). With respect to the treatment of fevers and parasites, the active extracts from plants belonging to the 'cumarin cluster', such as the herb of rue ( $R$. chalepensis) were recommended in DMM for the internal use of the treatment of tremor and shivering prior to fever attacks while the seeds of Seseli tortuosum against fevers in general. The hits belonging to the 'anthraquinone cluster', such as the roots of Rumex species and rhubarb (Rheum spp.) were recommended for the treatments of scabies and fevers, respectively. For L. officinale, L. nobilis and S. sisarum no uses related to fever and parasites are recorded in $D M M(40)$.

\section{Microfractionation and isolation of bioactive principles of selected antichagasic plant taxa from the DMM library}

For the isolation of active compounds from the $D M M$ library we selected extracts pertaining to three different phylogenetic groups, with taxa whose plant material was readily accessible. A major phylogenetic hotspot showing apparent antitrypanosomal selectivity was the anthraquinone cluster with the rhizomes of $R$. crispus (curly dock) and $R$. rhaponticum (rhapontic rhubarb) from the Polygonaceae family. The anthraquinones emodin and chrysophanol were identified in $R$. crispus and served as a basis for the subsequent preliminary SAR study (vide infra). Since the naphthoquinone derivative nepodin with known antimalarial activity (75) was isolated together with anthraquinones from $R$. crispus and likewise inhibited epimastigote proliferation, the potency of the extract may reflect additive effects. In general, naphthoquinones have been studied extensively in $T$. cruzi epimastigotes $(81,82)$ without leading to a successful translation to clinical trials (83). Extracts with antitrypanosomal activity from plants with distinct phylogenetic positions were those from $L$. nobilis (bay) (Lauraceae) and S. sisarum (skirret; Apiaceae). L. nobilis leaves contain a range of SLs which may explain the significant antichagasic effects of its extract in epimastigotes. Numerous studies have addressed the selective versus non-selective antitrypanosomal effects of SLs which are also widely present in Asteraceae (84-86). SLs like cynaropicrin and others can act as electrophiles and form adducts with biological nucleophiles, such as trypanothione, the parasitic equivalent of glutathione in mammalian cells $(26,87)$. The reason why $L$. nobilis (leaves) was ineffective in the infection assay could be due to the SLs reacting with thiols in host cells, e.g. glutathione, without reaching the parasite. It has been shown that $\mathrm{CHO}$ cells can produce glutathione upon stress (88). Thus, SLS undergoing a Michael-type addition with thiols are likely poorly bioavailable to infected tissues as they are detoxified by glutathione. Although the polyacetylene falcarindiol from $S$. sisarum had no inhibitory effect on $T$. cruzi, we cannot exclude the possibility that other polyacetylenes present in $S$. sisarum root may be more potent as indicated by the activity profile of the extract.

\section{SAR study of anthraquinones as antichagasic natural products in vitro}


Anthraquinones are condensed aromatic hydrocarbons found in different plant species known for their medical and dye applications (89). In Western pharmacopoeias, anthraquinone containing botanical drugs, such as Rhamnus spp. (Frangulae cotex and Rhamni purshiani cortex) or Rheum officinale (Rhei radix) are used as laxatives. The 9,10-anthracenedione scaffold, if bioavailable to the infected cells, could interfere with the parasite redox system as this scaffold can mediate the production of hydrogen peroxide or reactive oxygen species (ROS) via oxygen reduction in situ (90). Anthraquinones have been shown to interfere with redox reactions in cells (91). ROS generation is also the postulated mode of action of the approved antichagasic drug benznidazole (92). However, further studies will be necessary to uncover the underlying mode of action. To elaborate on our natural product drug discovery approach, the most active antichagasic secondary metabolite emodin (1,3,8-trihydroxy-6-methylanthracene-9, 10-dione) led us to explore in more detail the SAR of differentially substituted 9,10-anthracenediones. Trihydroxylated anthraquinones have already been shown to be trypanocidal (vide infra), but this study provides a first preliminary SAR study on 9,10anthracenediones for both $T$. cruzi epimastigote and parasite release from trypomastigote infected CHO cells. Different anthraquinones have been shown to exert moderate to good antimalarial, antibacterial and antiviral effects in vitro at low micromolar concentrations (93). In our study, emodin showed specific submicromolar inhibition of parasite release in $\mathrm{CHO}$ cells. Emodin was previously only tested on epimastigotes at high micromolar concentrations (94) where it inhibited casein kinase 1 with an $\mathrm{IC}_{50}$ value of $130 \mu \mathrm{M}(95)$, thus significantly less potent than in the trypomastigote infection assay shown here. Other reported effects of this natural product include antiinflammatory, antiosteoporosis, and antidepressant effects (93). Purpurin, a natural trihydroxylated anthraquinone, inhibited parasite release and showed a selectivity index $>100$. Rather unexpectedly, it did not inhibit epimastigote proliferation, which may be due to differences in $\mathrm{pH}$ between lysosomes and culture medium related to the trypanosomal uptake of anthraquinones. Purpurin has previously been shown to inhibit blood-stream trypomastigotes (96), but was not studied in cellular infection assays. Since anthraquinone glycosides in plant extracts can be deglycosylated and reduced to anthrones and anthranoles by gut bacteria (97), resulting in potent laxative effects, the systemic application of these compounds can be challenging. However, as exemplified by the drug diacerin (prodrug of rhein), low micromolar plasma concentrations can be achieved (98). Unfortunately, rhein showed no antitrypanosomal effects in our assays, possibly due to the carboxylic acid at C2. It is noteworthy that the most important botanical drug used in the context of CD among the Guarani also contains anthraquinones, thus giving strong support to the anthraquinone cluster being of potential relevance in the treatment of $C D$.

Overall, the comparative phylobioactivity-guided screening for in vitro antichagasic activity is an enabling tool in the discovery of natural products that may have a potential in CD drug development. The comparative profiling was further suitable for a pharmacological validation of a library with botanical drugs currently used in the context of $C D$ in Bolivia, thus challenging the ethno-directed CD bioprospecting approach. Moreover, our study led to the identification of biologically significant antichagasic phylogenetic hotspots that will serve for subsequent phytochemical investigations.

\section{Acknowledgements}

This study was funded by the EU Marie Curie Actions Initial Training Network (ITN) MedPlant (medplant.eu). We would like to acknowledge the Guaraní, Ayoreo, Chiquitano and Quechua informants who agreed to participate in the research, and the members of the communities for their hospitality and interest. Rossy Chávez de Michel and Stephan Beck from the National Herbarium Bolivia (LPB) identified the herbarium specimens. We thank Yonny Flores, Alberto Giménez and Efrain Salamanca (Universidad Mayor de San Andres) for technical assistance in the lab in Bolivia and for introducing the handling of $T$. cruzi. We acknowledge Matthias Rubin (University of Bern) for 
technical assistance in the lab and Peter Staub (Unica) for collecting DMM plant material and Laura Casu (Unica) for production of extracts. We thank Peter Bütikofer (University of Bern) for sharing the T. brucei strain and giving advice on its culturing.

\section{References}

1. Pérez-Molina JA, Molina I. Chagas disease. Lancet. 2018;391(12):82-94.

2. Coura JR, Borges-Pereira J. Chagas disease: 100 years after its discovery. A systemic review. Acta Trop [Internet]. 2010 Jul;115(1-2):5-13. Available from: http://linkinghub.elsevier.com/retrieve/pii/S0001706X10000884

3. Barrett MP, Burchmore RJ, Stich A, Lazzari JO, Frasch AC, Cazzulo JJ, et al. The trypanosomiases. Lancet [Internet]. 2003 Nov;362(9394):1469-80. Available from: http://linkinghub.elsevier.com/retrieve/pii/S0140673603146946

4. Conteh L, Engels T, Molyneux DH. Socioeconomic aspects of neglected tropical diseases. Lancet [Internet]. 2010;375:239-47. Available from: http://dx.doi.org/10.1016/S01406736(09)61422-7

5. World Health Organization. Chagas disease (American trypanosomiasis) [Internet]. 2018. Available from: http://www.who.int/news-room/fact-sheets/detail/chagas-disease(american-trypanosomiasis)

6. World Health Organization. Chagas disease in Latin America: an epidemiological update based on 2010 estimates. Wkly Epidemiol Rec. 2015;6(90):33-44.

7. Organización Panamericana de la Salud. Estimación cuantitativa de la enfermedad de Chagas en las Americas. OPS/HDM/CD/425-06 Organización Panamericana de la Salud. Montevideo, Uruguay; 2006.

8. Araújo-Jorge TC de, Medrano-Mercado N. Chagas disease in Bolivia: a brief review of the urban phenomena. Rev Biomédica [Internet]. 2009;20(3):236-44. Available from: http://www.revbiomed.uady.mx/pdf/rb092038.pdf

9. Cassab JRA, Noireau F, Guillén G. La Enfermedad de Chagas en Bolivia - Conocimientos científicos al inicio del Programa de Control (1998-2002). La Paz, Bolivia: Ministerio de Salud y Previsión Social; 1999. 127-133 p.

10. Teixeira ARL, Nascimento RJ, Sturm NR. Evolution and pathology in Chagas disease - A Review. Mem Inst Oswaldo Cruz. 2006;101(5):463-91.

11. Jr AR, Rassi A, Marin-neto JA. Seminar Chagas disease. 2010;

12. Ribeiro AL, Nunes MP, Teixeira MM, Rocha MOC. Diagnosis and management of Chagas disease and cardiomyopathy. Nat Rev Cardiol [Internet]. 2012 Jul 31;9(10):576-89. Available from: http://www.nature.com/doifinder/10.1038/nrcardio.2012.109

13. Coura JR, Castro SL de. A Critical Review on Chagas Disease Chemotherapy. Mem Inst Oswaldo Cruz [Internet]. 2002 Jan;97(1):3-24. Available from: http://www.scielo.br/scielo.php?script=sci_arttext\&pid=S007402762002000100001\&lng=en\&tIng=en 
14. Marin-Neto JA, Rassi Jr A, Avezum Jr A, Mattos AC, Rassi A. The BENEFIT trial: testing the hypothesis that trypanocidal therapy is beneficial. Mem Inst Oswaldo Cruz, Rio Janeiro. 2009;104:319-24.

15. Castro JA, DeMecca MM, Bartel LC. Toxic Side Effects of Drugs Used to Treat Chagas' Disease (American Trypanosomiasis). Hum Exp Toxicol [Internet]. 2006 Aug 2;25(8):471-9. Available from: http://journals.sagepub.com/doi/10.1191/0960327106het653oa

16. Jackson Y, Alirol E, Getaz L, Wolff H, Combescure C, Chappuis F. Tolerance and Safety of Nifurtimox in Patients with Chronic Chagas Disease. Clin Infect Dis [Internet]. 2010;51(10):e69-75. Available from: https://academic.oup.com/cid/articlelookup/doi/10.1086/656917

17. Quiroga R, Meneses L, Bussmann RW. Medicinal ethnobotany in Huacareta (Chuquisaca, Bolivia). J Ethnobiol Ethnomed. 2012;

18. Vandebroek I, Thomas E, Sanca S, Van Damme P, Van L Van, De Kimpe N. Comparison of health conditions treated with traditional and biomedical health care in a Quechua community in rural Bolivia. J Ethnobiol Ethnomed. 2008;4:1.

19. Bussmann RW, Paniagua Zambrana NY, Moya Huanca LA, Hart R. Changing markets Medicinal plants in the markets of La Paz and El Alto, Bolivia. J Ethnopharmacol [Internet]. 2016;193:76-95. Available from: http://dx.doi.org/10.1016/j.jep.2016.07.074

20. Cordell GA, Colvard MD. Some thoughts on the future of ethnopharmacology. J Ethnopharmacol. 2005;100(1-2):5-14.

21. Aufderheide AC, Salo W, Madden M, Streitz J, Buikstra J, Guhl F, et al. A 9,000-year record of Chagas' disease. Proc Natl Acad Sci U S A. 2004;101(7):2034-9.

22. Wink M. Medicinal plants: A source of anti-parasitic secondary metabolites. Molecules. 2012;17(11):12771-91.

23. Newman DJ, Cragg GM. Natural Products as Sources of New Drugs from 1981 to 2014. J Nat Prod. 2016;79(3):629-61.

24. Tsouh Fokou PV, Nyarko AK, Appiah-Opong R, Tchokouaha Yamthe LR, Ofosuhene M, Boyom FF. Update on Medicinal Plants with Potency on Mycobacterium ulcerans. Biomed Res Int. $2015 ; 2015$.

25. Llurba Montesino N, Kaiser M, Brun R, Schmidt TJ. Search for antiprotozoal activity in herbal medicinal preparations; new natural leads against neglected tropical diseases. Molecules. 2015;20(8):14118-38.

26. Zimmermann S, Oufir M, Leroux A, Krauth-Siegel RL, Becker K, Kaiser M, et al. Cynaropicrin targets the trypanothione redox system in Trypanosoma brucei. Bioorganic Med Chem [Internet]. 2013;21(22):7202-9. Available from: http://dx.doi.org/10.1016/j.bmc.2013.08.052

27. Cheuka PM, Mayoka G, Mutai P, Chibale K. The role of natural products in drug discovery and development against neglected tropical diseases. Molecules. 2017;22(1).

28. Buenz EJ, Verpoorte R, Bauer BA. The Ethnopharmacologic Contribution to Bioprospecting Natural Products. Annu Rev Pharmacol Toxicol. 2018;58(1):509-30.

29. Trotter RT, Logan MH. Informant consensus: a new approach for identifying potentially effective medicinal plants. New York: Ed. Bedfore Hills; 1986. 91-112 p.

30. Calderón Ál, Romero LI, Ortega-Barría E, Solís PN, Zacchino S, Gimenez A, et al. Screening of Latin American plants for antiparasitic activities against malaria, Chagas disease, and 
leishmaniasis. Pharm Biol. 2010;48(5):545-53.

31. Fournet A, Barrios AA, Muñoz V. Leishmanicidal and trypanocidal activities of Bolivian medicinal plants. J Ethnopharmacol. 1994;41(1-2):19-37.

32. Muñoz Ortiz V, Duchen Uriarte EP, Wagner F, Ferreira ME, Serna E, Torrez S, et al. Actividad tripanocida in vitro e in vivo de extractos etanólicos de algunas plantas medicinales bolivianas In vitro and in vivo trypanocidal activity, of ethanolic extracts from some bolivian medicinal plants. Biofarbo. 2010;18(1):69-75.

33. Rojas de Arias A, Inchausti A, Ascurrat M, Fleitas N, Rodriguez E, Fournet A. In vitro activity and mutagenicity of bisbenzylisoquinolines and quinones against Trypanosoma cruzi trypomastigotes. Phyther Res. 1994;8(3):141-4.

34. Forsyth C. From Lemongrass to Ivermectin: Ethnomedical Management of Chagas Disease in Tropical Bolivia. Med Anthropol [Internet]. 2017; Available from: https://www.tandfonline.com/doi/full/10.1080/01459740.2017.1360878

35. Bastien J. The Kiss of Death: Chagas' disease in the Americas. Salt Lake City: The University of Utah Press; 1998.

36. Izumi E, Ueda-Nakamura T, Dias Filho BP, Veiga Júnior VF, Nakamura CV. Natural products and Chagas' disease: A review of plant compounds studied for activity against Trypanosoma cruzi. Nat Prod Rep. 2011;28(4):809-23.

37. Muschietti L V, Ulloa JL. Natural sesquiterpene lactones as potential Trypanocidal and Leishmanicidal agents. Nat Prod Commun. 2016;11(10):1569-78.

38. Schmidt T, Khalid S, Romanha A, Alves T, Biavatti M, Brun R, et al. The potential of secondary metabolites from plants as drugs or leads against protozoan neglected diseases - part I. Curr Med Chem. 2012;19(14):2128-75.

39. Schmidt T, Khalid S, Romanha A, Alves T, Biavatti M, Brun R, et al. The potential of secondary metabolites from plants as drugs or leads against protozoan neglected diseases - part II. Curr Med Chem. 2012;19(14):2176-228.

40. Staub PO, Casu L, Leonti M. Back to the roots: A quantitative survey of herbal drugs in Dioscorides' De Materia Medica (ex Matthioli, 1568). Phytomedicine [Internet]. 2016;23(10):1043-52. Available from: http://dx.doi.org/10.1016/j.phymed.2016.06.016

41. Salm A, Gertsch J. Cultural perception of triatomine bugs and Chagas disease in Bolivia: a cross-sectional field study. Parasites and Vectors [Internet]. 2019;12(291). Available from: https://doi.org/10.1186/s13071-019-3546-0

42. Brenière SF, Bosseno MF, Noireau F, Yacsik N, Liegeard P, Aznar C, et al. Integrate Study of a Bolivian Population Infected by Trypanosoma cruzi, the Agent of Chagas Disease. Mem Inst Oswaldo Cruz. 2002;97(3):289-95.

43. Chippaux J-P, Postigo JR, Santalla JA, Schneider D, Brutus L. Epidemiological evaluation of Chagas disease in a rural area of southern Bolivia. Trans R Soc Trop Med Hyg [Internet]. 2008 Jun;102(6):578-84. Available from: http://www.ncbi.nlm.nih.gov/pubmed/18430443

44. Samuels AM, Clark EH, Galdos-Cardenas G, Wiegand RE, Ferrufino L, Menacho S, et al. Epidemiology of and Impact of Insecticide Spraying on Chagas Disease in Communities in the Bolivian Chaco. McCall PJ, editor. PLoS NegI Trop Dis [Internet]. 2013 Aug 1;7(8):e2358. Available from: http://dx.plos.org/10.1371/journal.pntd.0002358

45. Ministerio de Salud. Revista Epidemiologica [Internet]. La Paz, Bolivia; 2015. Available from: https://www.minsalud.gob.bo/images/Libros/epidemio/Revista-Epidemiologica_opt.pdf 
46. Gürtler RE. Sustainability of vector control strategies in the Gran Chaco Region: current challenges and possible approaches. Mem Inst Oswaldo Cruz. 2009;104(1):52-9.

47. The Plant List, Version 1.1 [Internet]. 2013 [cited 2019 Oct 17]. Available from: www.theplantlist.org

48. The Angiosperm Phylogeny Group., Chase MW, Christenhusz MJM, Fay MF, Byng JW, Judd WS, et al. An update of the Angiosperm Phylogeny Group classification for the orders and families of flowering plants: APG IV. Bot J Linn Soc. 2016;181(1):1-20.

49. Weckerle CS, de Boer HJ, Puri RK, van Andel T, Bussmann RW, Leonti M. Recommended standards for conducting and reporting ethnopharmacological field studies. J Ethnopharmacol [Internet]. 2018;210(July 2017):125-32. Available from: http://dx.doi.org/10.1016/j.jep.2017.08.018

50. Tutin TG, Burges NA, Chater AO, Edmonson JR, Heywood VH, Moore DM, et al. Flora Europaea I (2nd Edition) and Flora Europaea II-V. Cambridge: Cambridge University Press;

51. Salamanca Capusiri E, Ruiz Pinell G, Ticona Huallpara JC, Giménez Turba A. Método colorimétrico - XTT: como evaluación de alto rendimiento de sustancias con actividad leishmanicida. Biofarbo [Internet]. 2008;16:21-7. Available from:

http://www.revistasbolivianas.org.bo/pdf/rbfb/v16n1/v16n1a05.pdf

52. Benabdelaziz I, Gómez-Ruiz S, Benkhaled M, Carralero S, Schenker P, Salm A, et al. New cycloartane-type ester triterpenes from Euphorbia pterococca and biological evaluation. Fitoterapia [Internet]. 2018;127(February):271-8. Available from: http://linkinghub.elsevier.com/retrieve/pii/S0367326X18300303

53. Don R, loset JR. Screening strategies to identify new chemical diversity for drug development to treat kinetoplastid infections. Parasitology. 2014;141(1):140-6.

54. Brun R, Schonenberger M. Cultivation and in vitro cloning of procyclic culture forms of Trypanosoma brucei in a semi-defined medium. Short communication. Acta Trop. 1979;36(3):289-92.

55. Gertsch J, Thöni Tobler R, Brun R, Sticher O, Heilmann J. Antifungal, antiprotozoal, cytotoxic and piscicidal properties of justicidin $B$ and a new arylnaphthalide lignan from Phyllanthus piscatorum. Planta Med. 2003;69(5):420-4.

56. Muelas-Serrano S, Le-Senne A, Fernández-Portillo C, Nogal JJ, Ochoa C, Gómez-Barrio A. In Vitro and in Vivo Anti-Trypanosoma cruzi Activity of a Novel Nitro-derivative. Mem Inst Oswaldo Cruz, Rio Janeiro [Internet]. 2002 [cited 2017 Jun 14];97(4):553-7. Available from: http://www.scielo.br/pdf/mioc/v97n4/4461.pdf

57. Sullivan JJ. Metacyclogenesis cruzi in vitro: a simplified procedure. Trans R Soc Trop Med Hyg. 1982;76(3):300-3.

58. Da Silva CF, Junqueira A, Lima MM, Romanha AJ, Sales Junior PA, Stephens CE, et al. In vitro trypanocidal activity of DB745B and other novel arylimidamides against Trypanosoma cruzi. J Antimicrob Chemother. 2011;66(6):1295-7.

59. Oliveira Silva AC, Fonseca Santana E, Saraiva AM, Neves Coutinho F, Acre Castro RH, Caetano Pisciottano MN, et al. Which Approach Is More Effective in the Selection of Plants with Antimicrobial Activity? Evidence-based Complement Altern Med. 2013;2013.

60. Svetaz L, Zuljan F, Derita M, Petenatti E, Tamayo G, Cáceres A, et al. Value of the ethnomedical information for the discovery of plants with antifungal properties. A survey among seven Latin American countries. J Ethnopharmacol. 2010;127(1):137-58. 
61. Khafagi IK, Dewedar A. The efficiency of random versus ethno-directed research in the evaluation of Sinai medicinal plants for bioactive compounds. J Ethnopharmacol. 2000;71(3):365-76.

62. Quiroga R, Arrázola S. Etnobotánica médica en cuatro etnias de las tierras bajas de Bolivia: un enfoque comparativo Medicinal ethnobotany in four ethnic groups of the Bolivian lowlands: a comparative approach. Vol. 7, Revista de la Sociedad Boliviana de Botánica. 2013.

63. Heinrich M, Robles M, West JE, Ortiz de Montellano BR, Rodriguez E. Ethnopharmacology of Mexican Asteraceae (Compositae). Annu Rev Pharmacol Toxicol [Internet]. 1998;38(1):53965. Available from: http://www.annualreviews.org/doi/10.1146/annurev.pharmtox.38.1.539

64. Moerman DE, Pemberton RW, Kiefer D, Berlin B. A Comparative Analysis of five medicinal floras. J Ethnobiol [Internet]. 1999;19(1):49-67. Available from: https://ethnobiology.org/sites/default/files/pdfs/JoE/19-1/Moerman-etal.pdf

65. Thomas E, Vandebroek I, Sanca S, Van Damme P. Cultural significance of medicinal plant families and species among Quechua farmers in Apillapampa, Bolivia. J Ethnopharmacol. 2009;122(1):60-7.

66. Dave H, Ledwani L. A review on anthraquinones isolated from Cassia species and their applications. Indian J Nat Prod Resour. 2012;3(3):291-319.

67. Hajdu Z, Hohmann J. An ethnopharmacological survey of the traditional medicine utilized in the community of Porvenir, Bajo Paraguá Indian Reservation, Bolivia. J Ethnopharmacol [Internet]. 2012;139(3):838-57. Available from: http://dx.doi.org/10.1016/j.jep.2011.12.029

68. Moreira F V., Bastos JFA, Blank AF, Alves PB, Santos MR V. Chemical composition and cardiovascular effects induced by the essential oil of Cymbopogon citratus DC. Stapf, Poaceae, in rats. Rev Bras Farmacogn. 2010;20(6):904-9.

69. Lim TK. Edible Medicinal and Non-Medicinal Plants. In: Edible Medicinal and Non-Medicinal Plants. 2016. p. 196-213.

70. Luz AIR, Maia JGS, Silva ML, Zoghbi MGB, Ramos LS. Essential Oils of Some Amazonian Zingiberaceae, 3. Genera Alpinia and Rengalmia. J Nat Prod. 1984;47(5):907-8.

71. Martínez MR, Pochettino ML, Cortella AR. Environment and illness in the Calchaquí Valley (Salta, Argentina): Phytotherapy for osteo-articular and cardio-circulatory diseases. J Ethnopharmacol. 2004;95(2-3):317-27.

72. Report TD. Technical Data Report for CARQUEJA (Baccharis genistelloides). 2002; Available from: http://www.rain-tree.com/reports/carqueja-techreport.pdf

73. Mesquita Grandi TS, Da Trindade JA, Filardi Pinto MJ, Ferreira LL, Catella AC. Plantas medicinais de Minas Gerais, Brasil. Acta Bot Brasilica [Internet]. 1989;3(2):185-224. Available from: http://www.scielo.br/scielo.php?script=sci_arttext\&pid=S0102$33061989000300018 \& \operatorname{lng}=p t \& n r m=i s o \&$ tlng=pt

74. Martino VS. Problemática sanitaria y social de la enfermedad de Chagas. Aporte de la medicina tradicional argentina. Sanitary and social problematic of Chagas disease. Contribution of Argentine Traditional Medicine. Dominguezia. 2012;28(2):29-37.

75. Alonso JR. El lapacho. Rev Fitoter. 2000;1(2):107-17.

76. Bourdy G, Chavez De Michel LR, Roca-Coulthard A. Pharmacopoeia in a shamanistic society: The Izoceño-Guaraní (Bolivian Chaco). J Ethnopharmacol. 2004;91(2-3):189-208.

77. Sülsen VP, Cazorla SI, Frank FM, Redko FC, Anesini CA, Coussio JD, et al. Trypanocidal and 
Leishmanicidal Activities of Flavonoids from Argentine Medicinal Plants. Am J Trop Med Hyg. 2007;77(4):654-9.

78. Menna-Barreto RFS, Laranja GAT, Silva MCC, Coelho MGP, Paes MC, Oliveira MM, et al. AntiTrypanosoma cruzi activity of Pterodon pubescens seed oil: Geranylgeraniol as the major bioactive component. Parasitol Res. 2008;103(1):111-7.

79. Sepúlveda-Robles O, Espinoza-Gutiérrez B, Gomez-Verjan JC, Guzmán-Gutiérrez SL, De Ita M, Silva-Miranda $\mathrm{M}$, et al. Trypanocidal and toxicological assessment in vitro and in silico of three sesquiterpene lactones from Asteraceae plant species. Food Chem Toxicol [Internet]. 2019;125(December 2018):55-61. Available from: https://doi.org/10.1016/j.fct.2018.12.023

80. Schmidt TJ, Nour AMM, Khalid SA, Kaiser M, Brun R. Quantitative structure - Antiprotozoal activity relationships of sesquiterpene lactones. Molecules. 2009;14(6):2062-76.

81. Salas CO, Faundez M, Morello A, Maya JD, Tapia RA. Natural and Synthetic Naphthoquinones Active Against Trypanosoma Cruzi: An Initial Step Towards New Drugs for Chagas Disease. Curr Med Chem. 2011;18:144-61.

82. Ventura Pinto A, Lisboa de Castro S. The Trypanocidal Activity of Naphthoquinones: A Review. Molecules. 2009;14(11):4570-90.

83. Sales PA, Molina I, Murta SMF, Sánchez-Montalvá A, Salvador F, Corrêa-Oliveira R, et al. Experimental and clinical treatment of Chagas disease: A review. Am J Trop Med Hyg. 2017;97(5):1289-303.

84. Muschietti L V., Ulloa JL. Natural sesquiterpene lactones as potential trypanocidal therapeutic agents: A review. Nat Prod Commun. 2016;11(10):1569-78.

85. Kimani NM, Matasyoh JC, Kaiser M, Nogueira MS, Trossini GHG, Schmidt TJ. Complementary quantitative structure-activity relationship models for the antitrypanosomal activity of sesquiterpene lactones. Int J Mol Sci. 2018;19(12).

86. Moraes Neto RN, Setúbal RFB, Higino TMM, Brelaz-de-Castro MCA, da Silva LCN, Aliança AS dos S. Asteraceae Plants as Sources of Compounds Against Leishmaniasis and Chagas Disease. Front Pharmacol. 2019;10(May):1-20.

87. Zimmermann S, Fouché G, De Mieri M, Yoshimoto Y, Usuki T, Nthambeleni R, et al. StructureActivity relationship study of sesquiterpene lactones and their semi-synthetic amino derivatives as potential antitrypanosomal products. Molecules. 2014;19(3):3523-38.

88. Orellana CA, Marcellin E, Schulz BL, Nouwens AS, Gray PP, Nielsen LK. High-antibodyproducing chinese hamster ovary cells up-regulate intracellular protein transport and glutathione synthesis. J Proteome Res. 2015;14(2):609-18.

89. Malik EM, Müller CE. Anthraquinones As Pharmacological Tools and Drugs. Med Res Rev. 2016;36(4):705-48.

90. Campos-Martin JM, Blanco-Brieva G, Fierro JLG. Hydrogen peroxide synthesis: An outlook beyond the anthraquinone process. Angew Chemie - Int Ed. 2006;45(42):6962-84.

91. Okumura N, Mizutani H, Ishihama T, Ito M, Hashibe A, Nakayama T, et al. Study on Redox Properties and Cytotoxicity of Anthraquinone Derivatives to Understand Antitumor Active Anthracycline Substances. Chem Pharm Bull (Tokyo). 2019;67(7):717-20.

92. Pedrosa RC, de Bem AF, Locatelli C, Geremias R, Filho DW. Time-dependent oxidative stress caused by benznidazole. Redox Rep. 2004;6(4):265-70.

93. Li Y, Jiang JG. Health functions and structure-activity relationships of natural anthraquinones 
from plants. Food Funct. 2018;9(12):6063-80.

94. De Lima AR, Noris-Suárez K, Bretaña A, Contreras VT, Navarro MC, Pérez-Ybarra L, et al. Growth arrest and morphological changes triggered by emodin on Trypanosoma cruzi epimastigotes cultivated in axenic medium. Biochimie. 2017;142:31-40.

95. Justiniano I, Noris-Suarez K, De Lima AR, Contreras VT, Bubis J. An unusual casein kinase 1 from Trypanosoma cruzi epimastigotes. Biochem Compd. 2014;2(1):1.

96. De Castro S, Pinto M, Pinto A. Screening of natural and synthetic drugs against Trypanosoma cruzi. 1. Establishing a structure/activity relationship. Microbios. 1994;78(315):83-90.

97. Hattori M, Namba T, Akao T, Kobashi K. Metabolism of sennosides by human intestinal bacteria. Pharmacology. 1988;36(Suppl 1):172-9.

98. Nicolas P, Tod M, Padoin C, Petitjean O. Clinical Pharmacokinetics of Diacerein. Clin Pharmacokinet. 1998;35(5):347-59. 
bioRxiv preprint doi: https://doi.org/10.1101/862029; this version posted December 2, 2019. The copyright holder for this preprint (which was not certified by peer review) is the author/funder, who has granted bioRxiv a license to display the preprint in perpetuity. It is made available under aCC-BY 4.0 International license.

Table 1. Socio-demographic characteristics of the informants in the surveyed rural areas reporting knowledge about CD medicinal plants*, number of use reports and reported taxa.

\begin{tabular}{|c|c|c|c|c|c|c|c|c|c|}
\hline \multirow[b]{2}{*}{ Ethnicity } & \multirow[b]{2}{*}{ Geographical zone } & \multirow{2}{*}{$\begin{array}{c}\text { Total } \\
\text { Informants }\end{array}$} & \multicolumn{2}{|c|}{ Gender } & \multicolumn{3}{|c|}{ Age class } & \multirow{2}{*}{$\begin{array}{c}\text { Use } \\
\text { reports }\end{array}$} & \multirow{2}{*}{$\begin{array}{c}\text { Reported } \\
\text { taxa }\end{array}$} \\
\hline & & & $\mathbf{F}$ & $\mathbf{M}$ & $<40$ & 41 to 60 & $>60$ & & \\
\hline Ayoreo & Chiquitania & 5 & 3 & 2 & 1 & 4 & 0 & 5 & 3 \\
\hline Chiquitano & Chiquitania & 68 & 33 & 35 & 22 & 24 & 22 & 199 & 38 \\
\hline Guaraní & Chaco & 54 & 33 & 21 & 19 & 24 & 11 & 93 & 15 \\
\hline Quechua & Inter-andean valleys & 19 & 10 & 9 & 8 & 9 & 2 & 42 & 31 \\
\hline Total & & 146 & 79 & 67 & 50 & 61 & 35 & 339 & 87 \\
\hline
\end{tabular}

* responses of women sellers in herbal markets in La Paz and Santa Cruz cities are not included in this table. 
Table 2. List of plant species reported to be used in the treatment of Chagas disease and related symptoms by Ayoreo, Chiquitano, Guaraní and Quechua informants.

\begin{tabular}{|c|c|c|c|c|c|c|c|c|c|c|}
\hline $\begin{array}{l}\text { Family } \\
\text { Genus/species }\end{array}$ & Vernacular name & $\begin{array}{l}\text { Used } \\
\text { by }\end{array}$ & $\begin{array}{l}\text { Part } \\
\text { used }\end{array}$ & $\begin{array}{l}\text { No. use } \\
\text { reports }\end{array}$ & Application & $\begin{array}{l}\text { Origin } \\
\text { (status) }\end{array}$ & Habit & $\begin{array}{l}\text { Acute or } \\
\text { chronic } \\
\text { phase }\end{array}$ & $\begin{array}{l}\text { Indication } \\
\text { Chagas } \\
\text { symptom }\end{array}$ & $\begin{array}{l}\text { Voucher } \\
\text { specimen }\end{array}$ \\
\hline \multicolumn{11}{|l|}{ Amaranthaceae } \\
\hline Dysphania ambrosioides (L.) Mosyakin \& Clemants & Caré, paico & c & $L, R$ & 17 & Or & $N($ Cul) & herb & chro & CAR, GAS & ASMP33 \\
\hline \multicolumn{11}{|l|}{ Anacardiaceae } \\
\hline Astronium urundeuva (Allemao) Engl. & Cuchi & C & $B, L$ & 2 & Or & $N(W)$ & tree & chro & CAR & $\begin{array}{l}\text { ASMP56, } \\
\text { ASMP6 }\end{array}$ \\
\hline Schinus molle L. & Molle & Q & $\mathrm{L}$ & 2 & Or, Tp & $N(W)$ & tree & chro & CAR, GAS & ASMP90 \\
\hline \multicolumn{11}{|l|}{ Annonaceae } \\
\hline Annona nutans (R. E. Fr.) R. E. Fr. & Sinini, Aratiku, Sorimimi & G & L & 5 & Or & $N(W)$ & shrub & chro & CAR & ASMP11 \\
\hline Duguetia sp. & Sinini & c & L & 12 & Or & n.d. (Cul) & tree & chro & CAR & ASMP41 \\
\hline \multicolumn{11}{|l|}{ Apocynaceae } \\
\hline Aspidosperma quebrancho-blanco Schitdl. & Cacha & c & B & 8 & Or & $N(W)$ & tree & chro & CAR, FAT & ASMP35 \\
\hline Vallesia glabra (Cav.) Link & Amarguillo, Arakuarembiu & G & $\mathrm{L}$ & 3 & Or & $N(W)$ & tree & chro & CAR & ASMP17 \\
\hline \multicolumn{11}{|l|}{ Aristolochiaceae } \\
\hline Aristolochia andina F. Gonzáles \& I. Vargas & Waje & Q & $\mathrm{Br}, \mathrm{L}$ & 1 & Or & $N(W)$ & vine & chro & CAR & ASMP94 \\
\hline \multicolumn{11}{|l|}{ Asteraceae } \\
\hline Acanthostyles buniifolius (Hook. ex Hook. \& Arn.) & Romero & Q & AP & 2 & Or & $\mathrm{N}(\mathrm{Cul})$ & shrub & chro & FAT & ASMP82 \\
\hline Achyrocline alata (Kunth) DC. & Guacanqui, Wira wira & $C, L P$ & AP & 6 & Or & $\mathrm{N}($ Cul,Pur) & herb & chro & CAR & $\begin{array}{l}\text { ASMP45, } \\
\text { ASMP103 }\end{array}$ \\
\hline Achyrocline hyperchlora S. F. Blake & Wira wira & Q & AP & 2 & Or & $N(W)$ & herb & chro & CAR & ASMP91 \\
\hline Ambrosia arborescens Mill. & Altamisa & $\mathrm{Q}$ & $\mathrm{L}$ & 2 & Or & $N(W)$ & subshru & chro & CAR & ASMP83 \\
\hline Baccharis genistelloides (Lam.) Pers. & Carqueja, Kinsa k'ucho & $L P, Q$ & AP & 3 & Or & $N($ Pur, W) & herb & chro & CAR, GAS & $\begin{array}{l}\text { ASMP28, } \\
\text { ASMP85 }\end{array}$ \\
\hline Bidens andicola Kunth & Misuka & Q & AP & 1 & Or & $N(W)$ & herb & chro & PUR & ASMP89 \\
\hline Chromolaena connivens (Rusby) R.M. King \& H. Rob. & Sunchuj maman & Q & $\mathrm{Fr}, \mathrm{L}$ & 1 & Or & $N(W)$ & shrub & chro & FAT & ASMP75 \\
\hline Culcitium canescens Humb. \& Bonpl. & K'ia k'ia & LP & AP & 2 & Or & $N$ (Pur) & herb & chro & CAR & ASMP102 \\
\hline Cynara sp. & Alcachofa & LP, SC & AP & 2 & Or & n.d. (Pur) & herb & chro & CAR & ASMP13 \\
\hline Gochnatia boliviana S. F. Blake & Melinco & Q & $\mathrm{L}$ & 1 & Or & $N(W)$ & shrub & chro & CAR, FAT & ASMP87 \\
\hline Mutisia acuminata Ruiz \& Pav. & Chinchirkuma & Q & $\mathrm{Br}, \mathrm{L}$ & 1 & Or & $N(W)$ & shrub & chro & CAR & ASMP88 \\
\hline Parthenium hysterophorus L. & Artemisa, Chupurujumo & c & AP & 1 & Or & $N(W)$ & herb & acu, chro & FEV, PUR & ASMP59 \\
\hline Pluchea sagittalis (Lam.) Cabrera & 4 Cantos & c & $\mathrm{FI}, \mathrm{L}$ & 1 & Or & $\mathrm{N}(\mathrm{Cul})$ & shrub & chro & CAR & ASMP36 \\
\hline Schkuhria pinnata (Lam.) Kunza ex Thell. & Jayaj pichana & Q & AP & 2 & Or & $N(W)$ & herb & chro & CAR, FAT & ASMP76 \\
\hline Sonchus oleraceus L. & Diente de Leon & $C, L P$ & AP & 3 & Or & I (Pur) & herb & chro & CAR & $\begin{array}{l}\text { AMP12, } \\
\text { ASMP30 }\end{array}$ \\
\hline
\end{tabular}


Tajibo, Tajibo negro

Handroanthus impetiginosus (Mart. ex DC.) Mattos

Jacaranda cuspidifolia Mart.

Tabebuia aurea (Silva Manso) Benth. \& Hook. F. ex S. Bixaceae

Bixa orellana $\mathrm{L}$.

Caricaceae

Carica papaya L.

Cochlospermaceae

Cochlospermum tetraporum Hallier $\mathrm{f}$.

Cucurbitaceae

Momordica charantia L.

Ephedraceae

Ephedra americana Humb. \& Bonpl. Ex Willd.

Euphorbiaceae

Croton andinus Muell. Arg.

Croton sp.

Euphorbia serpens Kunth

Jatropha curcas L.

Fabaceae

Acacia aroma Gillies ex Hook. \& Arn.

Acacia sp.

Bauhinia sp.

Copaifera langsdorffii Desf.

Crotalaria incana $\mathrm{L}$.

Hymenaea courbaril L.

Pterodon sp.

Senna chloroclada (Harms) H. S. Irwin \& Barneby

Spartium junceum L.

Gesneriaceae

Gloxinia gymnostoma Griseb.

Gramineae

Cymbopogon citratus (DC.) Stapf

Labiatae

Clinopodium axillare (Rusby) Harley
Paraparau

Paratodo, Alcornoque

Uruku

Papaya

Kuari, Pela pela

Balsamina

Pisqo simi

Taporita, Tupeicha

K'uru k'uru

Quebra Pedra

Piñón

Tusca

Karikari

Patecabra

Copaibo

Amorocita

Paquío

Pezoe

Lanza lanza, Mbuijare, Retama

Retama

Ortelón

Paja de cedrón

Huayra Muña

$\begin{array}{ll}\text { Q } & \text { L } \\ \text { C, G } & \text { B, Fl } \\ \text { C } & \text { B } \\ \text { C, A } & \text { B } \\ \text { C, G } & \text { L } \\ \text { C, G } & \text { FI }\end{array}$

C, G $\quad \mathrm{Fl} \quad 3 \quad$ O

Or

G B, L 8 Or

AP

Or

Or

$N(W)$

$\mathrm{N}(\mathrm{W}) \quad$ herb

n.d. (W) herb

$\mathrm{N}(\mathrm{Cul})$ herb chro CAR, FAT ASMP49

I(Cul) treelet chro FAT

$\mathrm{N}(\mathrm{Cul})$ tree chro CAR $\quad$ ASMP24

n.d. (Cul) tree chro PUR ASMP43

n.d. (Cul) shrub acu, chro FEV, PUR ASMP42

$\mathrm{N}(\mathrm{W})$ tree chro CAR ASMP51

$N(W)$ herb chro $\quad$ FAT ASMP95

$\mathrm{N}(\mathrm{W})$ tree chro CAR, FAT ASMP55

$\mathrm{N}(\mathrm{W})$ tree chro FAT ASMP52

$\mathrm{N}(\mathrm{W})$ shrub acu, chro CAR, FEV ASMP10

I (Pur) shrub chro CAR ASMP100

$\mathrm{N}(\mathrm{Cul})$ herb chro CAR, FAT ASMP40

I (Cul) herb chro CAR, FAT ASMP31

N (Cul) subshru chro $\quad$ CAR $\quad$ ASMP80 
Lepechinia vesiculosa (Benth.) Epling

Minthostachys ovata (Briq.) Epl.

Ocimum americanum L.

Aloe vera (L.) Burm.f.

Linaceae

Linum usitatissimum

Malpighiaceae

Galphimia brasiliensis (L.) A. Juss.

sterile

Malvaceae

Malva parviflora L.

Meliaceae

Trichilia sp.

Myrtaceae

Myrcianthes callicoma McVaugh

Myrcianthes pseudomato (D. Legrand) McVaugh

Plinia cauliflora (Mart.) Kausel

Oxalidaceae

Hypseocharis pimpinellifolia Remy

Papaveraceae

Argemone subfusiformis G. B. Ownbey

Bocconia integrifolia Bonpl.

Passifloraceae

Passiflora cincinnata Mast.

Piperaceae

Piper rusbyi C. DC.

Plantaginaceae

Plantago major L.

Polygalaceae

Monnina wrightii A. Gray

Rosaceae

Rubus sp

Rutaceae

Heterophyllaea lycioides (Rusby) Sandwith

Ruta chalepensis L.

Zanthoxylum coco Gillies ex Hook. F. \& Arn. Solanaceae

Cestrum parqui L'Her.

\section{Raq'acho}

Muña

Albahaca

Sábila, karaguata guasu

Linaza

Masiaré

Azucaró

Malva

Tipa

Guapurú

K'arasacha

Guapurú

Sultaki

Cardo Santo

Turumi

Pachío, Mburukuya

Matico

Llantén

T'ian t'ian

Kari kari

Kapi

Ruda

Chirimolle

Andrés Huaylla

Q $\quad 1$

AP 3

Or

Or

$C$

Wh 2 Or

C, G La 5 Tp

Q $\quad \mathrm{Fr} \quad 2$

Or

$\begin{array}{llll}\text { A }, ~ C & R & 11 & \text { Or }\end{array}$

A $C$

$L P, Q \quad A P$

C, SC B

11

Q L

$\begin{array}{ll}Q & \text { L } \\ C & \text { L }\end{array}$

1

1
2
1

$\begin{array}{llll}\text { Q } & \text { R } & 1 & \mathrm{Tp}\end{array}$

C, G $\quad \mathrm{FI} \quad 3$

$\mathrm{Q}$

$C, G$

$\mathrm{Fl}, \mathrm{L}, \mathrm{R} \quad 13$

Q L 11 or

$\begin{array}{lll}\text { LP } & \text { AP }\end{array}$

Q $\quad$ L 11 Or

$\begin{array}{llll}Q & L & 1 & \text { Or } \\ Q & L & 1 & \text { Or }\end{array}$

$L P, Q \quad A P, L \quad 2 \quad$ Or

\begin{tabular}{|c|c|c|c|c|}
\hline$N(W)$ & shrub & chro & CAR & ASMP81 \\
\hline$N(C u l)$ & $\begin{array}{l}\text { subshru } \\
\text { b }\end{array}$ & chro & FAT, GAS & ASMP69 \\
\hline I (Cul) & herb & chro & CAR & ASMP48 \\
\hline I (Cul) & herb & acu & BIT, PUR & ASMP25 \\
\hline I (Cul) & herb & chro & PUR & ASMP71 \\
\hline $\mathrm{N}$ (Cul) & herb & chro & CAR, FAT & ASMP32 \\
\hline n.d. (W) & tree & chro & CAR & ASMP54 \\
\hline I (Cul,Pur) & herb & chro & CAR, FAT, & ASMP77, \\
\hline n.d. (Cul) & tree & chro & CAR & ASMP53 \\
\hline$N(W)$ & tree & chro & FAT & ASMP73 \\
\hline$N(W)$ & tree & chro & CAR, GAS & ASMP72 \\
\hline $\mathrm{N}(\mathrm{Cul})$ & tree & chro & CAR & ASMP60 \\
\hline$N(W)$ & herb & chro & FAT & ASMP70 \\
\hline$N(W)$ & herb & chro & CAR & ASMP20 \\
\hline$N(W)$ & tree & chro & FAT & ASMP97 \\
\hline$N(W)$ & vine & chro & CAR, FAT & ASMP16 \\
\hline $\mathrm{N}(\mathrm{Cul}, \mathrm{W})$ & shrub & chro & FAT, PUR & ASMP50, \\
\hline I (Cul) & herb & chro & CAR & ASMP47 \\
\hline$N(W)$ & herb & chro & CAR & ASMP84 \\
\hline n.d. (Pur) & herb & chro & CAR & ASMP101 \\
\hline$N(W)$ & shrub & chro & GAS & ASMP86 \\
\hline I (Cul) & herb & chro & GAS, PUR & ASMP99 \\
\hline$N(W)$ & tree & chro & CAR & ASMP74 \\
\hline N (Cul,Pur) & shrub & chro & CAR, GAS & ASMP78, \\
\hline
\end{tabular}


Urtica urens $\mathrm{L}$.

Ortiga

Valerianaceae

Valeriana potopensis Briq.

Jama jama

LP AP 11 Or

herb

chro

CAR

ASMP29

erbenaceae

Aloysia citriodora Palau

Cedrón

Aloysia polystachya (Griseb.) Moldenke

B, L 1

$N(W)$

herb

chro

Zingiberaceae

Poleo

Alpinia zerumbet (Pers.) B. L. Burtt \& R. M. Sm.

$\mathrm{C}, \mathrm{Q}$

$\begin{array}{lll}L & 4\end{array}$

$\mathrm{N}$ (Cul)

CAR

ASMP79

Colonia

C, G, SC

(Cul)

shrub

chro

CAR

ASMP37

Zygophyllaceae

Guayacán, Guayacán Morado

C, G B 3

Or

I (Cul)

herb chro

CAR

ASMP19

Bulnesia bonariensis Griseb

Or

$\mathrm{N}(\mathrm{Cul})$

tree

chro

CAR

ASMP23

Abbreviations: A:Ayoreo; C:Chiquitano; G:Guaraní; LP:La Paz; SC:Santa Cruz; AP:aerial parts; B:bark; Br:branches; Fl:flowers; Fr:fruit; La:latex; L:leaves; R:roots; Se:seeds; Wh:whole plant; Or:oral application; Tp:topical application; N:native; I: introduced; n.d.: not determined; Cul:cultivated; Pur:purchased at marktet; W:wild; chro:chronic; acu:acute; BIT:Vinchuca bite; CAR:cardiovascular symptoms; FEV:fever; GAS:gastrodigestive symptoms; FAT:fatigue; PUR:purifier/blood purifier/to strenghten the blood 
bioRxiv preprint doi: https://doi.org/10.1101/862029; this version posted December 2, 2019. The copyright holder for this preprint (which was not certified by peer review) is the author/funder, who has granted bioRxiv a license to display the preprint in perpetuity. It is made available under aCC-BY 4.0 International license.

Table 3. In vitro antiproliferative activity of compounds isolated from plant extracts on $T$. cruzi epimastigotestage $(72 \mathrm{~h})$ and trypomastigotes release $(6 \mathrm{dpi})$. Cytotoxic (antiproliferative) effects of the compounds were assessed on $\mathrm{CHO}$ host cells after $72 \mathrm{~h}$. CHO cells cultured in medium without FBS showed a reduced cytotoxicity towards sesquiterpene lactones than proliferating $\mathrm{CHO}$ cells. Data shown are mean values \pm SD of at least three independent experiments each performed in triplicates.

\begin{tabular}{|c|c|c|c|c|}
\hline Isolated cpd & $\begin{array}{c}\mathrm{IC}_{50} \text { epimastigotes } \\
{[\mu \mathrm{M}]}\end{array}$ & $\begin{array}{c}\text { \% inhibition of parasite } \\
\text { release } \\
\text { at } 5 \mu \mathrm{M}\end{array}$ & $\begin{array}{c}\mathrm{IC}_{50} \text { CHO cells } \\
{[\mu \mathrm{M}]}\end{array}$ & $\begin{array}{c}\mathrm{IC}_{50} \text { CHO cells } \\
\text { without FBS } \\
{[\mu \mathrm{M}]}\end{array}$ \\
\hline Nepodin * & $28.7 \pm 13.3$ & $34.7 \pm 30.9$ & $>100$ & n.d \\
\hline Torachrysone * & $>50$ & $25.9 \pm 15.5$ & $>100$ & n.d \\
\hline Emodin * & $14.1 \pm 8.2$ & $61.5 \pm 18.2$ & $>100$ & n.d \\
\hline Falcarindiol $^{+}$ & $>50$ & 0 & $>100$ & n.d \\
\hline Costunolide $^{\ddagger}$ & $7.4 \pm 5.9$ & 0 & $10.9 \pm 3.7$ & $35.4 \pm 13.8$ \\
\hline Reynosin $\#$ & $>50$ & $50.0 \pm 47.1$ & $31.3 \pm 8.0$ & $66.1 \pm 1.2$ \\
\hline Santamarine $\#$ & $19.5 \pm 9.3$ & $55.9 \pm 46.7$ & $13.2 \pm 4.3$ & $39.4 \pm 1.5$ \\
\hline Zaluzanin $C^{\#}$ & $6.7 \pm 0.7$ & $71.0 \pm 7.5$ & $6.6 \pm 1.7$ & $19.2 \pm 5.2$ \\
\hline 3-acetylzaluzanin C & $6.3 \pm 0.9$ & $83.0 \pm 10.1$ & $6.9 \pm 2.4$ & n.d \\
\hline Dehydrocostus lactone ${ }^{\#}$ & $1.4 \pm 0.4$ & $86.2 \pm 4.1$ & $5.8 \pm 1.9$ & $12.2 \pm 0.5$ \\
\hline Eremanthin ${ }^{\#}$ & $1.9 \pm 0.3$ & $87.6 \pm 9.9$ & $7.3 \pm 1.4$ & $11.5 \pm 0.2$ \\
\hline Bzn $(20 \mu \mathrm{M})$ & $13.8 \pm 2.9$ & $76.9 \pm 15.2$ & $>100$ & n.d \\
\hline
\end{tabular}

* Rumex crispus root, + Sium sisarum root, $\ddagger$ Rheum rhaponticum root, \# Laurus nobilis leaf 
Table 4. Chemical structures of natural and synthetic anthraquinones tested on T. cruzi.<smiles>[R]c1c([R])c([R])c2c(c1[R])C(=O)c1c([R])c([R])c([R])c([R])c1C2=O</smiles>

\begin{tabular}{|c|c|c|c|c|c|c|c|c|c|}
\hline ID & & R1 & R2 & R3 & R4 & R5 & R6 & R7 & R8 \\
\hline 1 & Anthraquinone & $\mathrm{H}$ & $\mathrm{H}$ & H & $\mathrm{H}$ & $\mathrm{H}$ & $\mathrm{H}$ & $\mathrm{H}$ & $\mathrm{H}$ \\
\hline 2 & Emodin & $\mathrm{OH}$ & $\mathrm{H}$ & $\mathrm{OH}$ & $\mathrm{H}$ & H & $\mathrm{CH}_{3}$ & H & $\mathrm{OH}$ \\
\hline 3 & Purpurin & $\mathrm{OH}$ & $\mathrm{OH}$ & $\mathrm{H}$ & $\mathrm{OH}$ & $\mathrm{H}$ & $\mathrm{H}$ & $\mathrm{H}$ & $\mathrm{H}$ \\
\hline 4 & Alizarin & $\mathrm{OH}$ & $\mathrm{OH}$ & $\mathrm{H}$ & $\mathrm{H}$ & $\mathrm{H}$ & $\mathrm{H}$ & $\mathrm{H}$ & $\mathrm{H}$ \\
\hline 5 & Alizarin RedS & $\mathrm{OH}$ & $\mathrm{OH}$ & $\mathrm{SO}_{2} \mathrm{ONa}$ & $\mathrm{H}$ & $\mathrm{H}$ & $\mathrm{H}$ & $\mathrm{H}$ & $\mathrm{H}$ \\
\hline 6 & Quinizarin & $\mathrm{OH}$ & $\mathrm{H}$ & $\mathrm{H}$ & $\mathrm{OH}$ & $\mathrm{H}$ & $\mathrm{H}$ & $\mathrm{H}$ & $\mathrm{H}$ \\
\hline 7 & Anthrarufin & $\mathrm{OH}$ & $\mathrm{H}$ & $\mathrm{H}$ & $\mathrm{H}$ & $\mathrm{OH}$ & $\mathrm{H}$ & $\mathrm{H}$ & $\mathrm{H}$ \\
\hline 8 & Dantron & $\mathrm{OH}$ & $\mathrm{H}$ & $\mathrm{H}$ & $\mathrm{H}$ & $\mathrm{H}$ & $\mathrm{H}$ & $\mathrm{H}$ & $\mathrm{OH}$ \\
\hline 9 & Anthraflavic acid & $\mathrm{H}$ & $\mathrm{OH}$ & $\mathrm{H}$ & $\mathrm{H}$ & $\mathrm{H}$ & $\mathrm{OH}$ & $\mathrm{H}$ & $\mathrm{H}$ \\
\hline 10 & Chrysophanol & $\mathrm{OH}$ & $\mathrm{H}$ & $\mathrm{CH}_{3}$ & $\mathrm{H}$ & $\mathrm{H}$ & $\mathrm{H}$ & $\mathrm{H}$ & $\mathrm{OH}$ \\
\hline 11 & Aloe-emodin & $\mathrm{OH}$ & $\mathrm{H}$ & $\mathrm{CH}_{2} \mathrm{OH}$ & $\mathrm{H}$ & $\mathrm{H}$ & $\mathrm{H}$ & $\mathrm{H}$ & $\mathrm{OH}$ \\
\hline 12 & Physcion & $\mathrm{OH}$ & $\mathrm{H}$ & $\mathrm{CH}_{3} \mathrm{O}$ & $\mathrm{H}$ & $\mathrm{H}$ & $\mathrm{CH}_{3}$ & $\mathrm{H}$ & $\mathrm{OH}$ \\
\hline 13 & 2-Hydroxy-3-methylanthraquinone & $\mathrm{H}$ & $\mathrm{OH}$ & $\mathrm{CH}_{3}$ & $\mathrm{H}$ & $\mathrm{H}$ & $\mathrm{H}$ & $\mathrm{H}$ & $\mathrm{H}$ \\
\hline 14 & 2-Hydroxy-1-methylanthraquinone & $\mathrm{CH}_{3}$ & $\mathrm{OH}$ & $\mathrm{H}$ & $\mathrm{H}$ & H & $\mathrm{H}$ & H & $\mathrm{H}$ \\
\hline 15 & Rhein & $\mathrm{H}$ & $\mathrm{COOH}$ & H & $\mathrm{OH}$ & $\mathrm{OH}$ & $\mathrm{H}$ & H & $\mathrm{H}$ \\
\hline 16 & Diacerein & $\mathrm{H}$ & $\mathrm{COOH}$ & H & $\mathrm{CH}_{3} \mathrm{COO}$ & $\mathrm{CH}_{3} \mathrm{COO}$ & $\mathrm{H}$ & H & $\mathrm{H}$ \\
\hline 17 & Disperse Red11 & $\mathrm{NH}_{2}$ & $\mathrm{CH}_{3} \mathrm{O}$ & H & $\mathrm{NH}_{2}$ & H & $\mathrm{H}$ & $\mathrm{H}$ & $\mathrm{H}$ \\
\hline 18 & Aurantio obtusin & $\mathrm{OH}$ & $\mathrm{CH}_{3} \mathrm{O}$ & $\mathrm{OH}$ & $\mathrm{H}$ & H & $\mathrm{CH}_{3}$ & $\mathrm{OH}$ & $\mathrm{CH}_{3} \mathrm{O}$ \\
\hline
\end{tabular}


bioRxiv preprint doi: https://doi.org/10.1101/862029; this version posted December 2, 2019. The copyright holder for this preprint (which was not certified by peer review) is the author/funder, who has granted bioRxiv a license to display the preprint in perpetuity. It is made available under aCC-BY 4.0 International license.

Table 5. In vitro antiproliferative activity of anthraquinones on $T$. cruzi epimastigotes $(72 \mathrm{~h})$ and trypomastigotes release $(6 \mathrm{dpi})$. Compounds that inhibited at least $20 \%$ of parasite release in the trypomastigote infection assay at $0.5 \mu \mathrm{M}$ were tested for antiproliferative effects on $\mathrm{CHO}$ host cells. Data shown are mean values \pm SD of at least three independent experiments each performed in triplicates.

\begin{tabular}{|c|c|c|c|}
\hline ID & $\begin{array}{c}\mathrm{IC}_{50} \text { epimastigotes } \\
{[\mu \mathrm{M}]}\end{array}$ & $\begin{array}{c}\text { \% inhibition of parasite } \\
\text { release } \\
\text { at } 0.5 \mu \mathrm{M}\end{array}$ & $\begin{array}{c}\mathrm{IC}_{50} \mathrm{CHO} \text { cells } \\
{[\mu \mathrm{M}]}\end{array}$ \\
\hline 1 & $>50$ & $17.8 \pm 11.8$ & n.d. \\
\hline 2 & $14.1 \pm 8.1$ & $53.2 \pm 24.3$ & $>100$ \\
\hline 3 & $>50$ & $52.5 \pm 14.4$ & $59.5 \pm 10.1$ \\
\hline 4 & $>50$ & 0 & n.d. \\
\hline 5 & $>50$ & 0 & n.d. \\
\hline 6 & $>50$ & $33.4 \pm 20.1$ & $38.1 \pm 16.0$ \\
\hline 7 & $>50$ & 0 & n.d. \\
\hline 8 & $5.3 \pm 2.3$ & 0 & n.d. \\
\hline 9 & $>50$ & $22.4 \pm 14.7$ & $77.8 \pm 1.7$ \\
\hline 10 & $6.6 \pm 3.5$ & 0 & n.d. \\
\hline 11 & $14.5 \pm 5.6$ & $26.6 \pm 21.9$ & $42.0 \pm 15.5$ \\
\hline 12 & $6.4 \pm 3.7$ & $18.1 \pm 16.7$ & n.d. \\
\hline 13 & $>50$ & 0 & n.d. \\
\hline 14 & $>50$ & $30.5 \pm 7.9$ & $88.9 \pm 8.9$ \\
\hline 15 & $>50$ & 0 & n.d. \\
\hline 16 & $>50$ & 0 & n.d. \\
\hline 17 & $32.9 \pm 13.9$ & 0 & n.d. \\
\hline 18 & $>50$ & 0 & n.d. \\
\hline Benznidazole & $13.8 \pm 2.9$ & 0 & $>100$ \\
\hline
\end{tabular}


bioRxiv preprint doi: https://doi.org/10.1101/862029; this version posted December 2, 2019. The copyright holder for this preprint (which was not certified by peer review) is the author/funder, who has granted bioRxiv a license to display the preprint in perpetuity. It is made available under aCC-BY 4.0 International license.

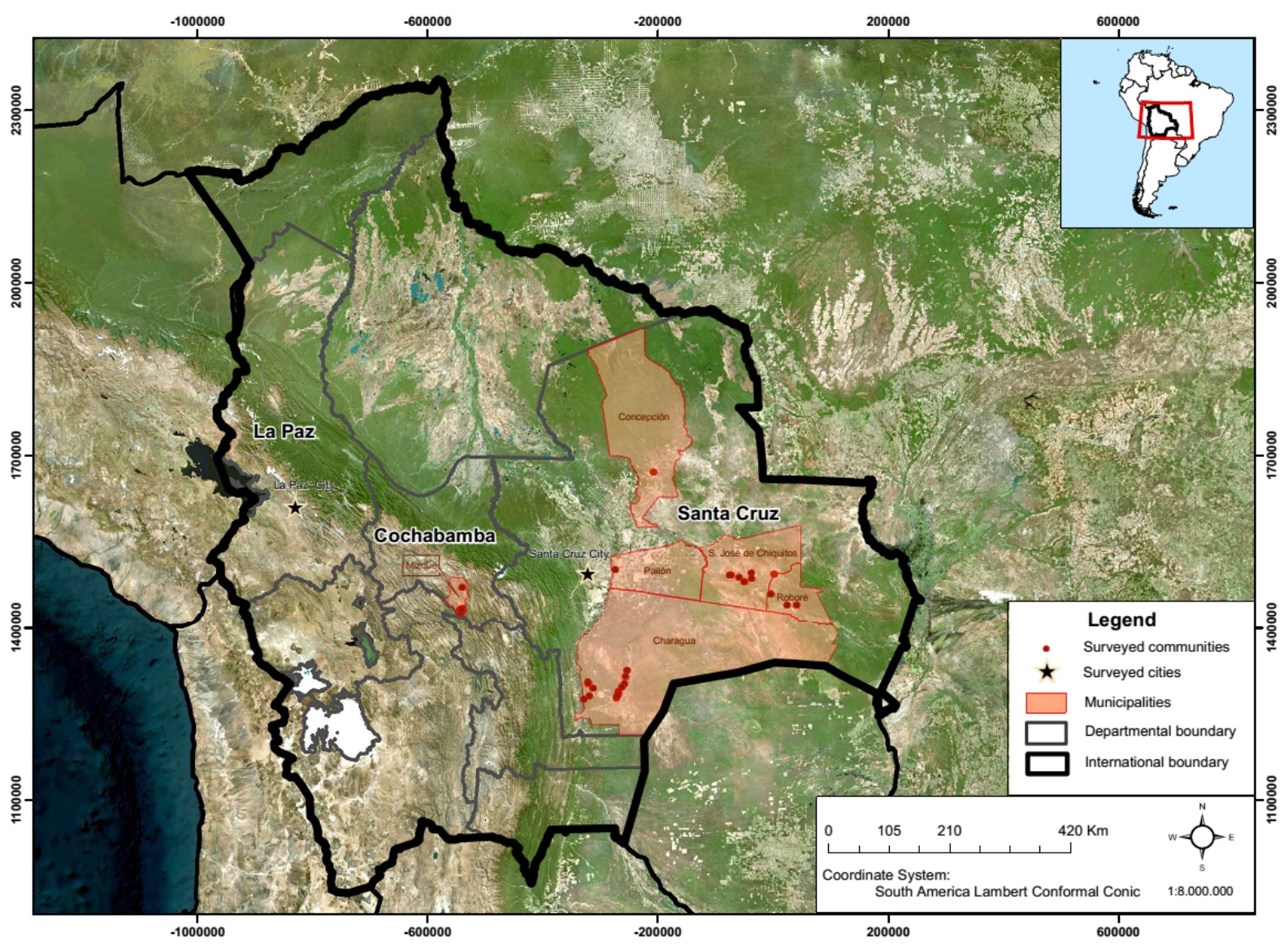

Figure 1. Areas of the ethnopharmacological field study in Bolivia. The three different municipalities (orange), surveyed communities (red dots) and cities (stars) are shown. The map was generated using the GPS coordinates with ArcGIS, version 10.3. 
bioRxiv preprint doi: https://doi. org/101101/862029; this version posted December 2, 2019. The copyright holder for this preprint (which was not certified by peer review) is the author/funder, who has granted bioRxiv a license to display the preprint in perpetuity. It is made available under aCC-BY 4.0 International license.

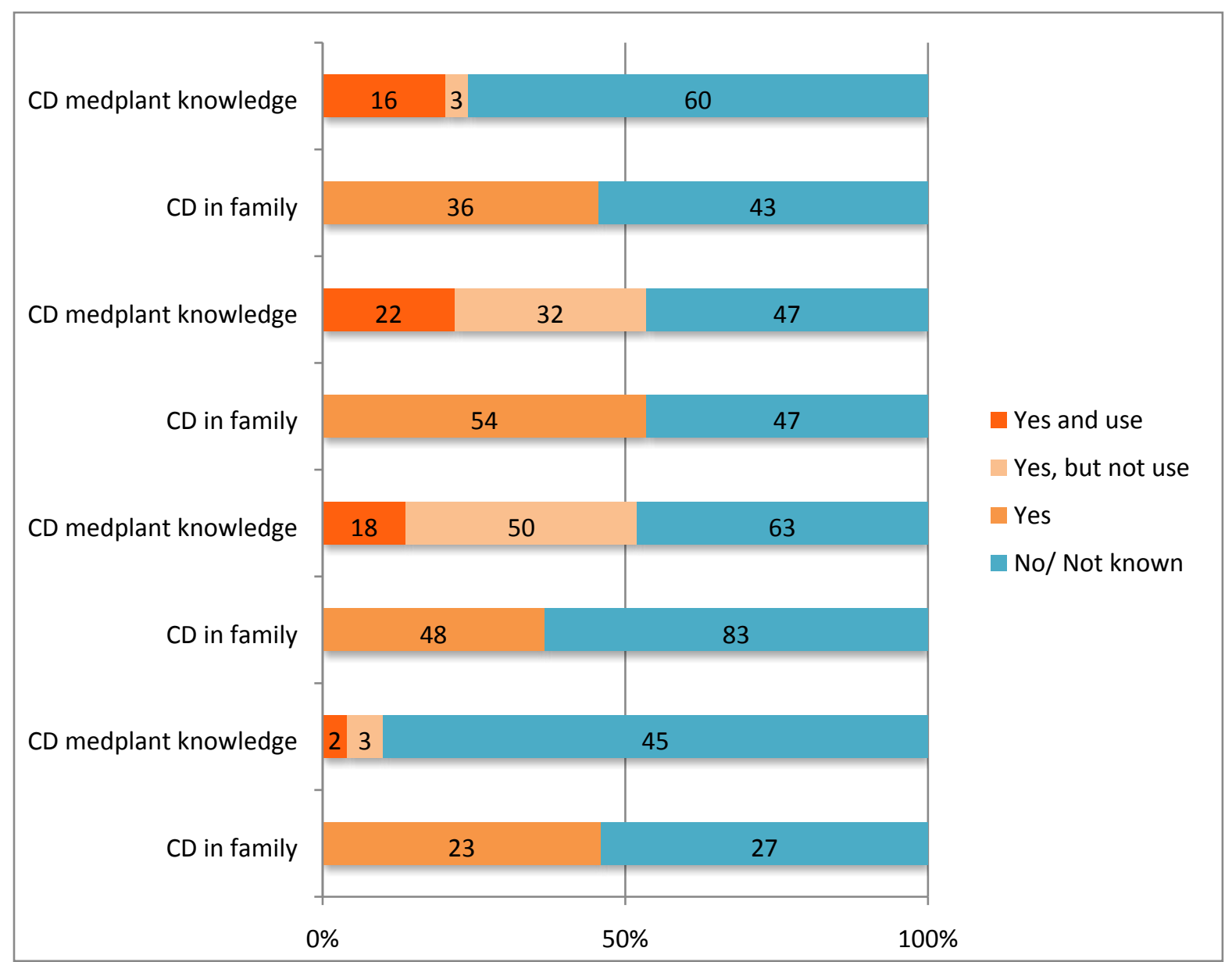

Figure 2. Graphical summary of the ethnomedical data. The number of informants from the four ethnic groups reporting knowledge and use of CD medicinal plants/agents (CD medplant knowledge), and the corresponding stated occurrence of $C D$ in the family (CD in family) are shown. 
bioRxiv preprint doi: https://doi.org/101101/862029; this version posted December 2, 2019. The copyright holder for this preprint (which was not certified by peer review) is the author/funder, who has granted bioRxiv a license to display the preprint in perpetuity. It is made available under aCC-BY 4.0 International license.
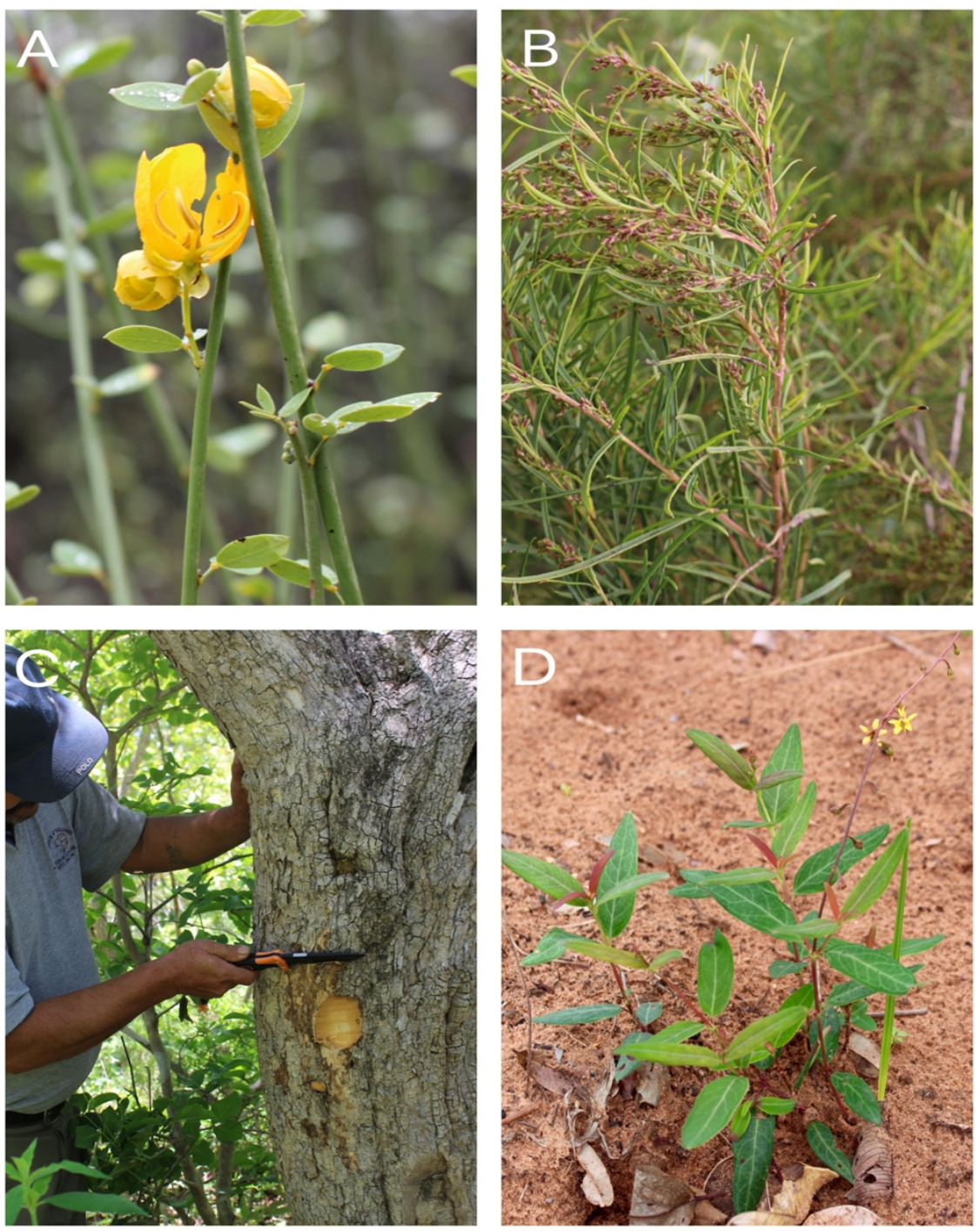

Figure 3. Selected Bolivian plant species used to treat symptoms related to CD. (A) Senna chloroclada flowers and roots were the most frequently cited botanical drugs among the Izoceño-Guaraní showing significant selective antichagasic effects on cellular parasite release in vitro. (B) Acanthostyles buniifolius was used by the Quechua and exhibited selective antichagasic activity in vitro. (C) Chiquitano informant cutting tree bark of Jacaranda cuspidifolia (D) The roots of Galphimia brasiliensis are used by the Chiquitano to treat symptoms related to CD. 
bioRxiv preprint doi: https://doi org/10 1101/862029; this version posted December 2, 2019. The copyright holder for this preprint (which was not certified by peer review) is the author/funder, who has granted bioRxiv a license to display the preprint in perpetuity. It is made available under aCC-BY 4.0 International license.
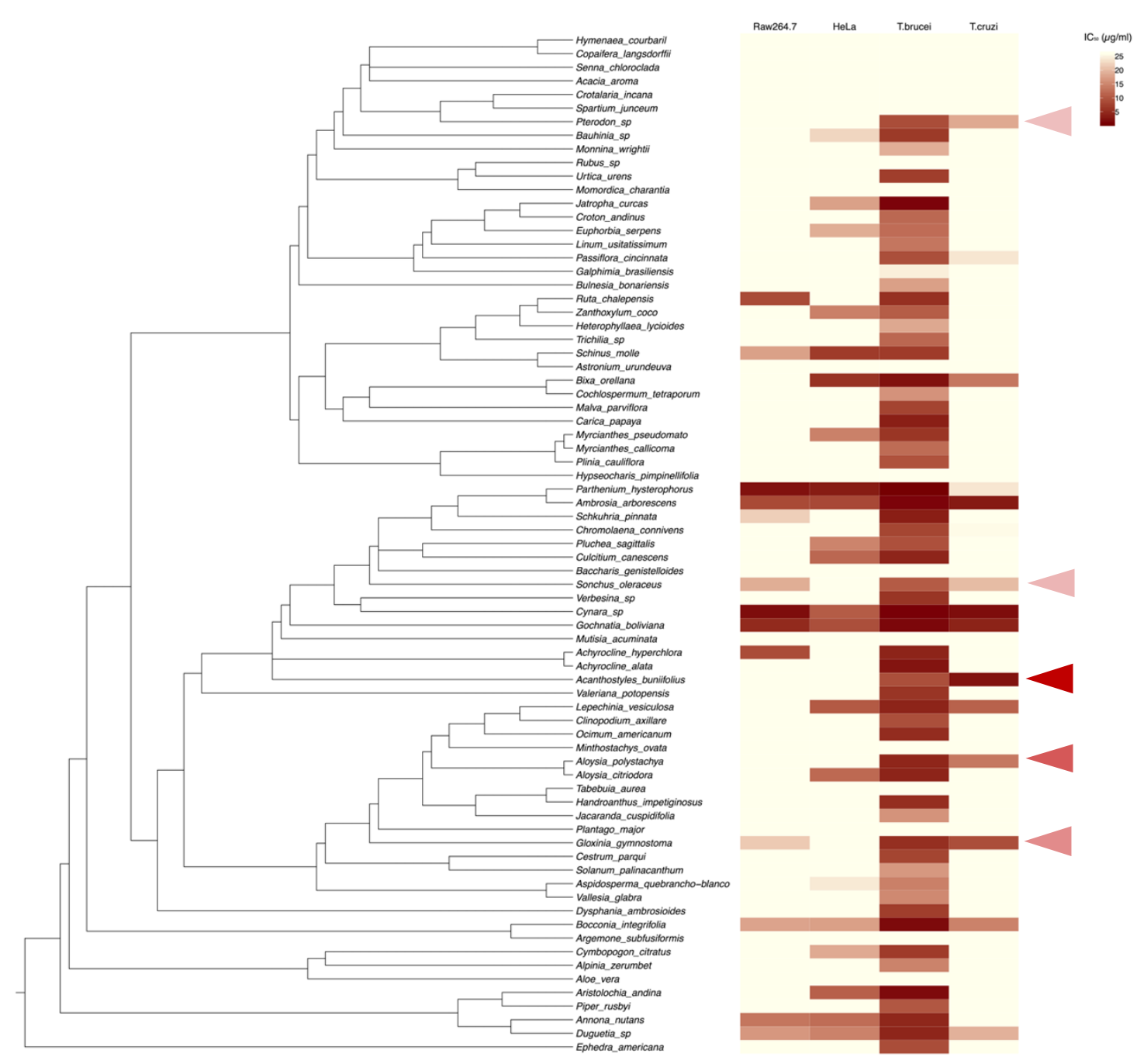

Figure 4. Phylobioactivity profiling of the EtOAc extract library generated from Bolivian medicinal plants used to treat symptoms of CD (reported plant part used). Few extracts showed selective toxicity towards $T$. cruzi epimastigotes with $\mathrm{IC}_{50}$ values below $20 \mu \mathrm{g} / \mathrm{mL}$ (arrows). There was a high of extracts toxic for procyclic $T$. brucei, and many showed antiproliferative effects in HeLa and Raw264.7 cells. The Leguminosae was the only subfamily cluster (top) showing no bioactivities up to $25 \mathrm{\mu g} / \mathrm{mL}$. In the sesquiterpene lactone rich family Asteraceae, only Acanthostyles buniifolius showed selective antitrypanosomal effects. Data represent profiling values from at least two independent screening assays each performed in triplicates. 
bioRxiv preprint doi: https://doi org/10 1101/862029; this version posted December 2, 2019. The copyright holder for this preprint (which was not certified by peer review) is the author/funder, who has granted bioRxiv a license to display the preprint in perpetuity. It is made available under aCC-BY 4.0 International license.

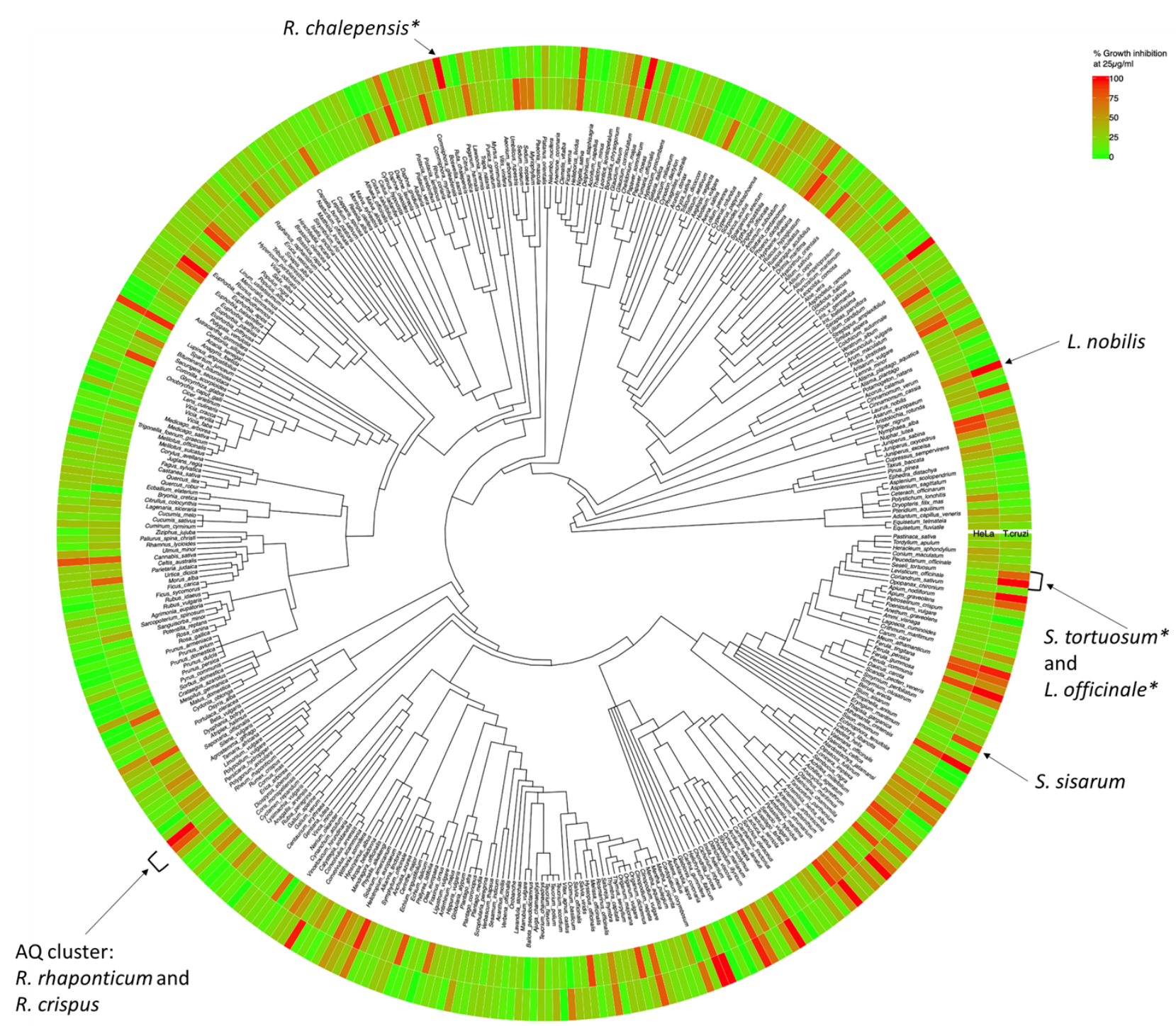

Figure 6. Phylobioactivity tree displaying phylogenetic relationships associated with bioactivities. The outer ring shows growth inhibition on $T$. cruzi epimastigotes, and the inner ring shows grows inhibition of HeLa cells (both at $25 \mu \mathrm{g} / \mathrm{mL}$; most active plant part shown only). A hypothetical coumarin cluster $(*)$ (Ruta chalepensis root, Levisticum officinale seeds and Seseli tortuosum root) and the anthraquinone cluster (Rhumex crispus and Rheum rhaponticum rhizoma) are visible. Laurus nobilis root and fruits and Sium sisarum root (microfractionated) are indicated in the phylogenic tree. Detailed data on plant species and activities are shown in supplementary Table $2 \mathrm{~S}$. 

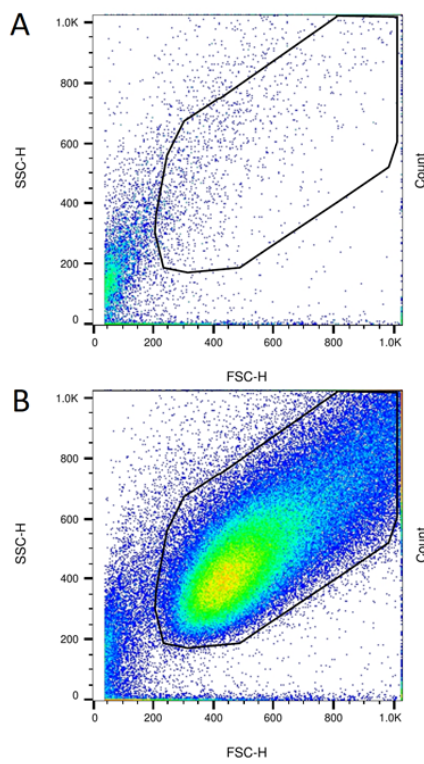

FSC.H

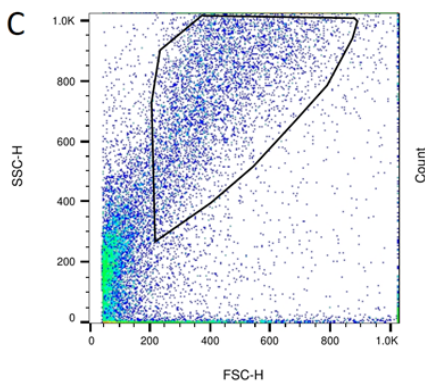

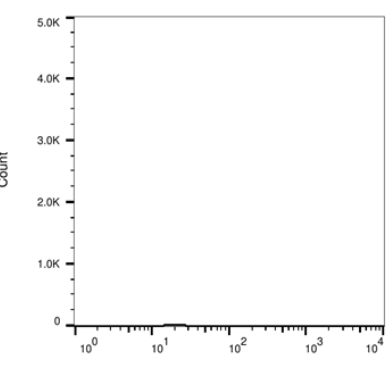
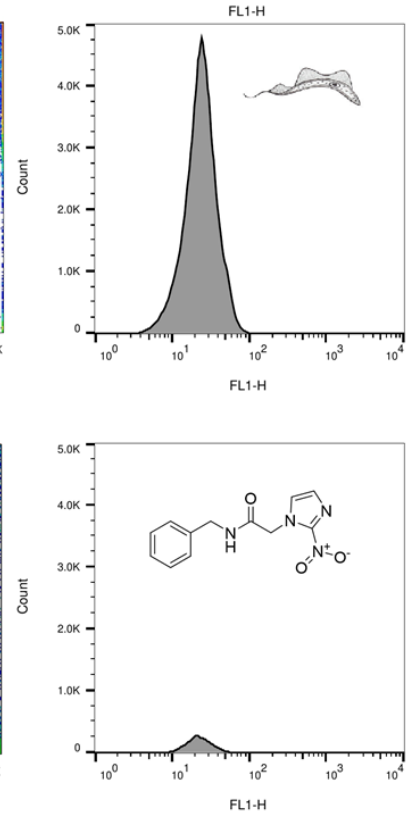

D
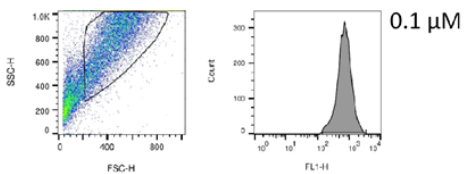

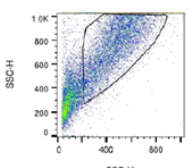
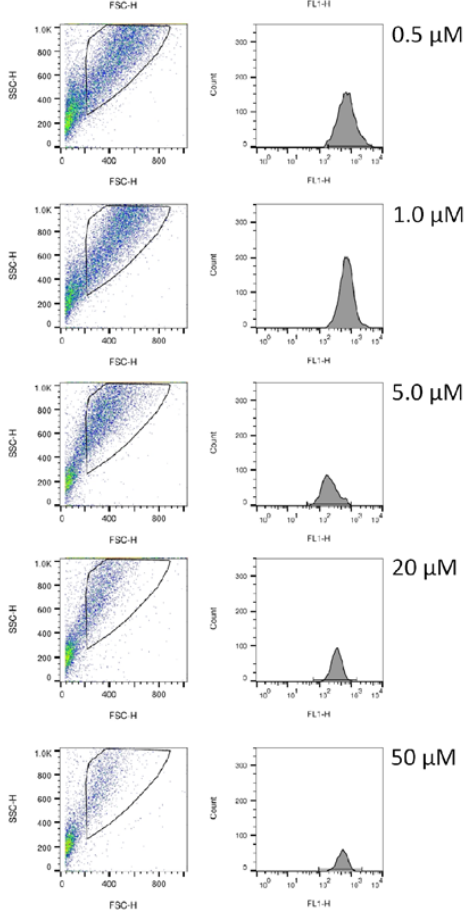

Figure 5. FACS-based trypomastigote infection assay in $\mathrm{CHO}$ cells. $\mathrm{CHO}$ cells were infected with trypomastigotes (10:1) for $24 \mathrm{~h}$, washed, and incubated in low FBS (1\%) medium for 6 days. Extracts dissolved in DMSO, vehicle and positive controls were added after washing and left for 6 days. Parasites released into the media at $6 \mathrm{dpi}$ were stained with SYTO'M green fluorescent nucleic acid stain, fixed with $4 \%$ paraformaldehyde and collected for FACS analysis. (A) Negative control of noninfected cells at 6 dpi showing FSC/SSC and FL1 histograms. (B) Positive control showing fluorescence associated to parasites at 6 dpi showing FSC/SSC and FLI1 histograms. (C) Representative example of benznidazole $(\mathrm{Bnz})$ treatment $(20 \mu \mathrm{M})$ at 6 dpi showing FSC/SSC and FL1 histograms illustrative of reduced parasite release. (D) Illustration of concentration-dependent effect by Benznidazol (Bnz) leading to decrease of parasites in medium at $6 \mathrm{dpi}$ with a calculated $\mathrm{IC}_{50}$ value of $2 \pm 0.4 \mu \mathrm{M}$ (maximal efficacy about 75\%). 


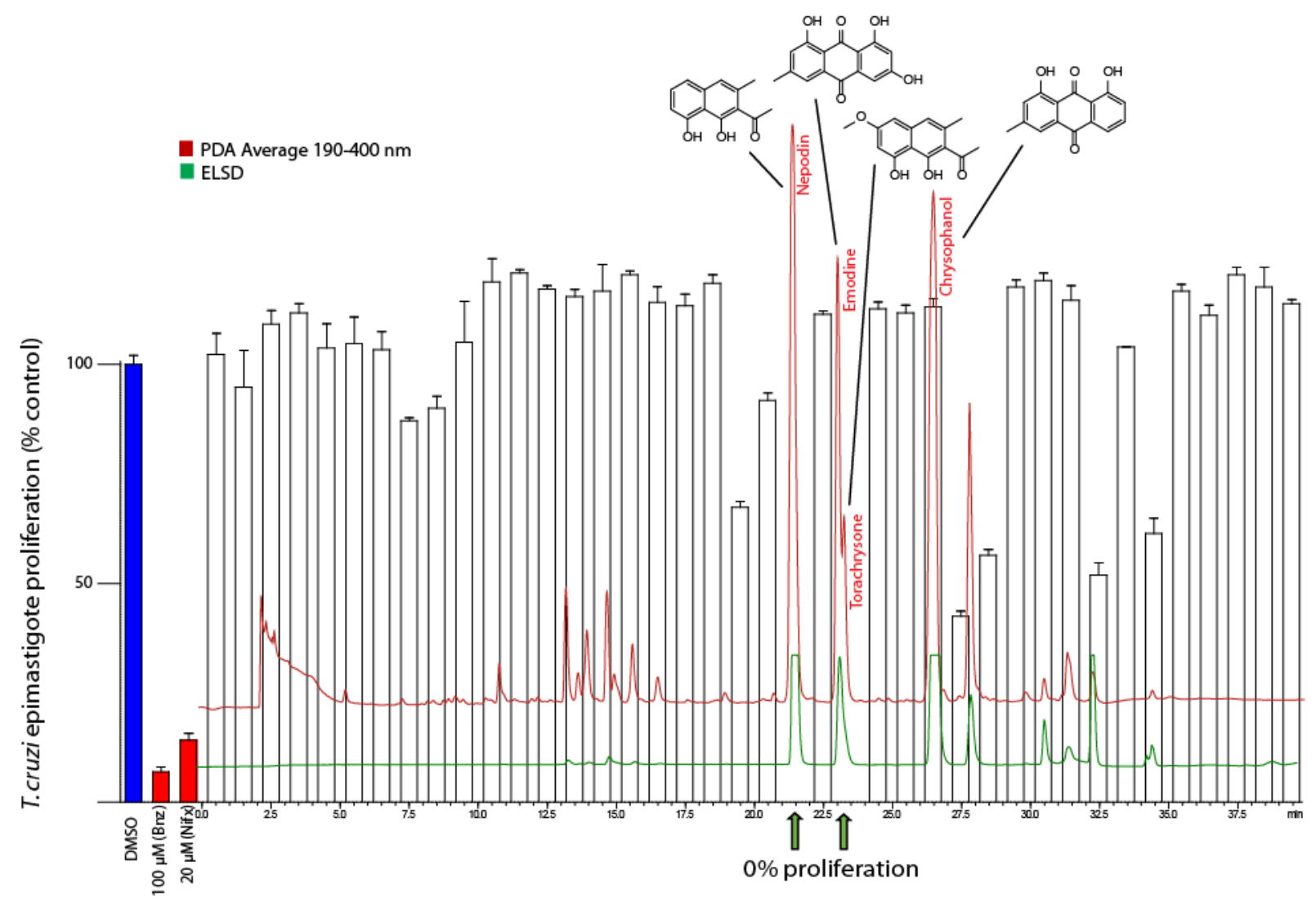

Figure 7. Bioactivity-guided microfractionation exemplified by $R$. crispus using photo diode array (PDA) and evaporative light scattering detectors (ELSD). Isolation of antichagasic metabolites was based on epimastigote proliferation inhibition. A limitation of this qualitative approach are false negatives (shown here with chrysophanol) due to low concentrations. Nepodin and emodin/torachrysone were identified and isolated from fully active fractions ( $0 \%$ cell viability), the moderately active chrysophanol was identified in a negative fraction. 